\title{
Use of molecular genetics for understanding seabird evolution, ecology and conservation
}

\author{
Scott A. Taylor, Vicki L. Friesen* \\ Department of Biology, Queen's University, Kingston, Ontario K7L 3N6, Canada
}

\begin{abstract}
Information on genetic variation within and among populations of highly mobile organisms such as seabirds is necessary for understanding their evolution and ecology, and can be a tool for conservation. Recent developments in molecular genetics, including efficient mutationdetection methods and automated sequencing, are providing detailed genetic information for non-model organisms. Furthermore, theoretical advances such as coalescent theory and molecular assignments are providing powerful tools to determine species' historical and contemporary abundance, distributions and movements. We review advances for studying phylogenetics, population genetics, hybridization, ecology and conservation in seabirds and summarize recent studies in each field. All fields will benefit from larger data sets and more sophisticated analytical methods. Phylogenetic studies will provide a more robust determination of evolutionary history, while studies of population genetics and hybridization will be elevated to genomic-level avenues of inquiry. Ecological studies may benefit from improved molecular assignments, and conservationfocussed studies will benefit from an increased understanding of seabird evolution and ecology. In addition, we highlight that combination of new molecular and analytical tools with data on morphology, behaviour and movements is especially powerful for understanding seabird evolution and ecology, and for aiding conservation.
\end{abstract}

KEY WORDS: Gene flow · Hybridization · Molecular assignments · Population genetic structure · Phylogeography $\cdot$ Phylogenetics $\cdot$ Population size $\cdot$ Review

Resale or republication not permitted without written consent of the publisher

\section{INTRODUCTION}

If you are interested in evolution and ecology, why study seabirds? As a group, seabirds possess a number of extreme life history characteristics that make them particularly good model organisms for DNAbased research into evolution and ecology: they can travel great distances, thus violating assumptions of many population divergence and speciation models, yet they generally exhibit natal philopatry (return to the site of birth to reproduce); and, although their breeding sites can be difficult to access, seabirds generally breed in large colonies from which sufficient samples can be collected for robust genetic analyses. Additionally, seabirds tend to be behaviourally complex, and their reliance on the marine environment makes them good candidate species to study in relation to climate change and other anthropogenic effects. This review explores uses of molecular genetics for understanding seabird evolution and ecology, and highlights the usefulness of this research to understanding broader evolutionary and ecological questions.

Early studies of morphology, behaviour and ecology of seabirds provided much information on their evolution, including estimates of genetic relationships among populations, species and higher taxa (e.g. Storer 1952, van Tets 1965, Nelson 1970, Strauch 1985, see also review by Schreiber \& Burger 2002). However, the genetic basis of morphological and behavioural characters is generally unknown, and inferences are limited to patterns, rather than ecological and evolutionary processes. Subsequently, molecular tools such as protein electrophoresis and 
DNA-DNA hybridization provided more direct information on population genetic structure, hybridization and phylogenetic relationships (e.g. Sibley 1970, Sibley \& Ahlquist 1990). For example, protein electrophoresis revealed the very close genetic related- ness of some Larus spp. (white-headed gull; Snell 1991), and indicated that Atlantic puffins Fratercula arctica from different colonies are genetically similar, despite significant differences in body size (Moen 1991)

Table 1. Summary of 2nd and 3rd generation DNA sequencing methods and platforms

\begin{tabular}{|c|c|}
\hline Method & Description \\
\hline \multicolumn{2}{|c|}{ 2nd generation (next generation) } \\
\hline \multirow[t]{4}{*}{454 pyrosequencing } & Parallelized version of pyrosequencing \\
\hline & $\begin{array}{l}\text { Pyrosequencing uses luciferase to generate light for detection of } \\
\text { individual nucleotides added to the growing DNA strand }\end{array}$ \\
\hline & $\begin{array}{l}\text { Uses emulsion PCR (DNA amplified inside water droplets; each } \\
\text { droplet contains } 1 \text { DNA template attached to } 1 \text { primer-coated bead, } \\
\text { which forms a clonal body }\end{array}$ \\
\hline & DNA can be extended $>1$ nucleotide at a time \\
\hline \multirow[t]{6}{*}{ Illumina (Solexa) } & Sequencing based on reversible dye-termination \\
\hline & $\begin{array}{l}\text { DNA molecules attach to primers on a slide - causes formation of } \\
\text { local clonal bodies (bridge PCR) }\end{array}$ \\
\hline & $\begin{array}{l}\text { Four types of reversible terminator bases added to reaction, } \\
\text { nucleotides that are not incorporated are washed away }\end{array}$ \\
\hline & Images taken of the fluorescently labeled nucleotides \\
\hline & $\begin{array}{l}\text { Dye and terminal } 3 \text { ' blocker chemically removed - allows next cycle } \\
\text { to begin }\end{array}$ \\
\hline & DNA only extended by 1 nucleotide at a time \\
\hline \multirow[t]{5}{*}{ SOLiD } & Sequencing by ligation \\
\hline & DNA amplified by emulsion PCR before sequencing \\
\hline & $\begin{array}{l}\text { Resulting beads (each contains only copies of the same DNA } \\
\text { molecule) deposited on slide }\end{array}$ \\
\hline & $\begin{array}{l}\text { Pool of oligonuceotides of fixed length labeled according to } \\
\text { sequenced position; annealed and ligated }\end{array}$ \\
\hline & $\begin{array}{l}\text { Preferential ligation for matching sequences produces signal } \\
\text { informing nucleotide at that position }\end{array}$ \\
\hline
\end{tabular}

Cheaper than 454 pyrosequencing, similar price to SOLiD; shorter read length than both Sanger and 454

Cheaper than 454 pyrosequencing, similar price to SOLiD; shorter read length than both Sanger and 454 pyrosequencing, comparable read length to Illumina

Cheaper and faster than any 2 nd generation platform, similar read length to 454 pyrosequencing,

System uses a microwell plate (different DNA in each well), wells are flooded with a single type of nucleotide, if nucleotide incorporates a hydrogen ion, it is released and read as the correct base

Multiple bases can be added simultaneously if they are the same type

DNA nanoball Rolling circle replication amplifies small fragments of genomic DNA into DNA nanoballs

Sequencing by ligation (unchained) used to determine nucleotide sequence

Helioscope $^{\mathrm{TM}}$ single molecular

Extension based sequencing (1 nucleotide at a time as with Sanger sequencing)

Uses DNA fragments with added poly-A tail adaptors

Cyclic washes with fluorescently labeled nucleotides occur, and reads are performed by Helioscope sequencer

Single molecular real time (SMRT ${ }^{\mathrm{TM}}$ )
Sequencing by synthesis approach with unmodified polymerase and fluorescently labeled nucleotides
Low cost compared to other methods, but short read lengths

Low cost compared to other methods, but short read lengths

Relatively low cost; 1000 bp read lengths 
Table 2 (this and following page). Summary of computer programs for analysis of molecular data, modified from Tables 1 \& 2 in Excoffier \& Heckel (2006), with the addition of programs for phylogenetic and ecological investigations. POPG, population genetics; POPD, population dynamics; HYB, hybridization; PHY, phylogenetics. MULT, multi-allelic markers (no specific mutation model assumed); DNA, sequence data; STR, short tandem repeat also known as microsatellites (stepwise mutation assumed); hapSTR, linked SNP and STR markers; SNP, single nucleotide polymorphism; FREQ, frequency data; AFLP, amplified fragment length polymorphism; DIST, distance matrix; RAPD, random amplified polymorphic DNA

\begin{tabular}{|c|c|c|c|c|c|}
\hline Program & Discipline & Functions & Data type & Platform & Source \\
\hline Structure & $\begin{array}{l}\text { POPG, } \\
\text { POPD, } \\
\text { HYB }\end{array}$ & $\begin{array}{l}\text { Uses genotypes from multiple markers to determine un- } \\
\text { derlying genetic structure among a set of individuals; } \\
\text { can detect immigrants; use in assignment studies }\end{array}$ & MULT & Java & Pritchard et al. (2000) \\
\hline NewHybrids & HYB & $\begin{array}{l}\text { Designed for the analysis of a single hybrid population; } \\
\text { samples can only come from } 2 \text { parental populations }\end{array}$ & MULT & Windows, Linux & $\begin{array}{l}\text { Anderson \& Thompson } \\
\text { (2002) }\end{array}$ \\
\hline IM, IMA, IMa2 & $\begin{array}{l}\text { POPG, } \\
\text { HYB }\end{array}$ & $\begin{array}{l}\text { Isolation model testing; multiple versions with migration, } \\
2 \text { population model can estimate divergence time, an- } \\
\text { cestral population size, divergence time, and migration }\end{array}$ & $\begin{array}{l}\text { DNA, STR, } \\
\text { hapSTR }\end{array}$ & DOS, MacOS & $\begin{array}{l}\text { Nielsen \& Wakeley (2001), } \\
\text { Hey \& Nielsen (2004, } \\
\text { 2007) }\end{array}$ \\
\hline DIYABC & $\begin{array}{l}\text { POPG, } \\
\text { HYB }\end{array}$ & $\begin{array}{l}\text { Make inferences based on Approximate Bayesian Comp- } \\
\text { utation; graphical interface }\end{array}$ & STR & Windows, Linux & Cornuet et al. (2008) \\
\hline Migrate & $\begin{array}{l}\text { POPG, } \\
\text { POPD, } \\
\text { HYB }\end{array}$ & $\begin{array}{l}\text { Estimates the effective population sizes and migration } \\
\text { rates of } 2 \text { constant populations using non-recombining } \\
\text { sequences, microsatellite data, or enzyme electro- } \\
\text { phoretic data }\end{array}$ & $\begin{array}{l}\text { DNA, SNP, STR, } \\
\text { MULT }\end{array}$ & $\begin{array}{l}\text { DOS, MacOS, } \\
\text { Linux }\end{array}$ & $\begin{array}{l}\text { Beerli \& Felsenstein (1999) } \\
\text { Beerli \& Palczewski } \\
\text { (2010) }\end{array}$ \\
\hline Bayes Ass + & POPG & $\begin{array}{l}\text { Uses multilocus genotypes to estimate contemporary } \\
\text { migration between populations }\end{array}$ & MULT & $\begin{array}{l}\text { Windows, } \\
\text { MacOS, Linux }\end{array}$ & Wilson \& Rannala (2003) \\
\hline Cfit & НYB & $\begin{array}{l}\text { Fits genotypic and phenotypic data to equilibrium cline } \\
\text { models }\end{array}$ & MULT & Windows & Gay et al. (2008) \\
\hline ClineFit & HYB & Fits genotypic data to equilibrium cline models & MULT & $\begin{array}{l}\text { Windows, } \\
\text { MacOS }\end{array}$ & Porter et al. (1997) \\
\hline BAPS & POPG & $\begin{array}{l}\text { Assigns individuals to genetic clusters; can consider } \\
\text { them immigrants or descendents from immigrants }\end{array}$ & MULT & Windows & Corander et al. $(2003,2004)$ \\
\hline GeneClass2 & POPG & $\begin{array}{l}\text { Uses multilocus genotypes to assign individuals to } \\
\text { populations and detect immigrants }\end{array}$ & MULT & Windows & Piry et al. (2004) \\
\hline Geneland & POPG & $\begin{array}{l}\mathrm{R} \text { package that takes into account spatial positions of } \\
\text { individuals when detecting population subdivisions }\end{array}$ & MULT & $\mathrm{R}$ & Guillot et al. (2005) \\
\hline Arlequin & POPG & $\begin{array}{l}\text { Multi-use population genetics software environment; } \\
\text { computes indices of genetic diversity, } F \text {-statistics, } \\
\text { Hardy-Weinberg Equilibrium, etc. }\end{array}$ & $\begin{array}{l}\text { DNA, SNP, STR, } \\
\text { MULT, FREQ }\end{array}$ & Windows & Excoffier et al. (2005) \\
\hline DnaSP & POPG & $\begin{array}{l}\text { Estimates several measures of DNA sequence variation } \\
\text { within and between populations including linkage } \\
\text { disequilibrium, recombination, gene flow and gene } \\
\text { conversion }\end{array}$ & DNA, SNP & Windows & Librado \& Rozas (2009) \\
\hline FSTAT & POPG & Multiple functions $-F_{\mathrm{ST}}$ estimates, etc. & STR, MULT & Windows & Goudet (1995) \\
\hline GDA & POPG & Multiple functions; basic indices of genetic diversity & AFLP, MULT & Windows & Lewis \& Zaykin (2002) \\
\hline Genepop & POPG & Multiple function; basic indices of genetic diversity & STR, MULT & DOS & Raymond \& Rousset (1995) \\
\hline GENETIX & POPG & Multiple function; basic indices of genetic diversity & MULT & Windows & Belkhir et al. (1996-2004) \\
\hline MEGA & POPG & Multiple function; basic indices of genetic diversity & DNA, DIST & Windows & Tamura et al. (2011) \\
\hline MSA & POPG & Multiple function; basic indices of genetic diversity & STR, MULT & $\begin{array}{l}\text { DOS, MacOS, } \\
\text { Linux }\end{array}$ & Lipman et al. (1989) \\
\hline SPAGeDi & POPG & $\begin{array}{l}\text { Computes genetic distance between populations, in- } \\
\text { breeding, kinship, relatedness }\end{array}$ & STR, MULT & $\begin{array}{l}\text { DOS, Windows, } \\
\text { MacOS, Linux }\end{array}$ & Hardy \& Vekemans (2002) \\
\hline BATWING & POPG & $\begin{array}{l}\text { Generation Bayesian inference, demographic history, } \\
\text { population splits }\end{array}$ & STR, SNP & $\begin{array}{l}\text { DOS, MacOS, } \\
\text { Linux }\end{array}$ & Wilson \& Rannala (2003) \\
\hline COLONISE & POPG & $\begin{array}{l}\text { Uses multilocus genotypes to study patterns of coloni- } \\
\text { zation events in population histories }\end{array}$ & MULT & Windows & Foll \& Gaggiotti (2005) \\
\hline
\end{tabular}


Table 2 (continued)

\begin{tabular}{|c|c|c|c|c|c|}
\hline Program & Discipline & Functions & Data type & Platform & Source \\
\hline LAMARC & POPG & $\begin{array}{l}\text { For estimating the historical demographics of a number } \\
\text { of populations }\end{array}$ & DNA, SNP, STR & $\begin{array}{l}\text { DOS, MacOS, } \\
\text { Linux }\end{array}$ & Kuhner (2006) \\
\hline MSVAR & POPG & $\begin{array}{l}\text { For estimating the historical demographics of a number } \\
\text { of populations (expansions and bottlenecks) }\end{array}$ & STR & DOS, Linux & Beaumont (1999) \\
\hline Hickory & POPG & $\begin{array}{l}\text { Software for analysis of geographic structure in genetic } \\
\text { data. Estimates F-statistics from dominant or co- } \\
\text { dominant marker data }\end{array}$ & $\begin{array}{l}\text { AFLP, } \\
\text { RAPD, MULT }\end{array}$ & Windows, Linux & Holsinger (1999) \\
\hline BOTTLENECK & POPG & Detects recent effective population size reductions & MULT & Windows & Cornuet \& Luikart (1996) \\
\hline GENETREE & PHY & Phylogeny reconstruction & DNA & DOS & Griffiths \& Tavaré (1994) \\
\hline PARENTE & POPD & Paternity analysis of genetic data & STR, SNP & Windows & Cercueil et al. (2002) \\
\hline CERVUS & POPD & Paternity analysis of genetic data & STR, SNP & Windows & Marshall et al. (1998) \\
\hline PATRI & POPD & Paternity analysis of genetic data & STR, SNP, RFLP & Windows, Linux & Nielsen et al. (2001) \\
\hline PROBMAX & POPD & Paternity analysis of genetic data & STR, SNP & DOS & Danzmann (1997) \\
\hline BAli-Phy & PHY & Phylogeny reconstruction & DNA & & Redelings \& Suchard (2005) \\
\hline BayesPhylogenies & PHY & Phylogeny reconstruction & DNA & & Pagel \& Meade (2004) \\
\hline BEAST & PHY & Phylogeny reconstruction & DNA & & $\begin{array}{l}\text { Drummond \& Rambaut } \\
\quad(2007)\end{array}$ \\
\hline BUCKy & PHY & Phylogeny reconstruction & DNA & & Ané et al. (2007) \\
\hline Mesquite & $\begin{array}{l}\text { PHY, } \\
\text { POPG, } \\
\text { POPD }\end{array}$ & Phylogeny reconstruction & DNA & & $\begin{array}{l}\text { Maddison \& Maddison } \\
\quad(2011)\end{array}$ \\
\hline MrBayes & $\begin{array}{l}\text { PHY, } \\
\text { POPG }\end{array}$ & Phylogeny reconstruction & DNA & & $\begin{array}{l}\text { Huelsenbeck \& Ronquist } \\
\text { (2001) }\end{array}$ \\
\hline PAML & PHY & Phylogeny reconstruction & DNA & $\begin{array}{l}\text { Windows, Unix, } \\
\text { Linux, MacOS }\end{array}$ & Yang (1997) \\
\hline PAUP* & PHY & Phylogeny reconstruction & DNA & $\begin{array}{l}\text { Windows, Unix, } \\
\text { MacOS }\end{array}$ & Swofford (2002) \\
\hline PHYLIP & PHY & Phylogeny reconstruction & DNA & $\begin{array}{l}\text { Windows, DOS, } \\
\text { MacOS }\end{array}$ & Felsenstein (1989) \\
\hline TOPALi & PHY & Phylogeny reconstruction & DNA & Java & Milne et al. (2004) \\
\hline Treefinder & PHY & Phylogeny reconstruction & DNA & Java & Jobb et al. (2004) \\
\hline
\end{tabular}

Increasingly sophisticated DNA-based technologies, especially sequencing methods (Table 1), in combination with new approaches to data analysis (Table 2; Excoffier \& Heckel 2006) are now allowing researchers not only to infer genetic relationships among populations and species, but also to address previously intractable questions in both evolution and ecology (Table 3, Fig. 1 ). Topics now accessible to researchers include (1) rediscovery of species thought to be extinct (e.g. Steeves et al. 2010), (2) identification of speciation events driven by mechanisms previously thought to be improbable (e.g. Friesen et al. 2007a), (3) coevolutionary dynamics of seabirds, their parasites and their immunogenetics (e.g. McCoy et al. 2005a, Bollmer et al. 2007), (4) understanding why some seabirds exist as highly differentiated populations while others exhibit little genetic differentiation across large distances (e.g. Morris-Pocock et al. 2010, Taylor et al. 2010a; see also review by Friesen et al. 2007b), (5) estimates of historical and contemporary population sizes and movements (e.g. Peery et al. 2008, Boessenkool et al. 2010), and (6) definition of population units for conservation (e.g. Friesen et al. 2005). Additionally, the developing field of ecological genomics (Dupont et al. 2007, Mitchell-Olds et al. 2008, Stapley et al. 2010) is enabling researchers to determine the genetic underpinning of morphological and physiological 
Table 3. Potential advances in major sub-disciplines of marine ornithology due to advances in molecular genetics, in particular new sequencing technology and new analytical techniques

\begin{tabular}{|c|c|}
\hline Sub-discipline & Advance \\
\hline Phylogenetics & $\begin{array}{l}\text { Genome-level phylogeny construction } \\
\text { Larger marker sets } \\
\text { Community phylogenetics }\end{array}$ \\
\hline $\begin{array}{c}\text { Population } \\
\text { genetics }\end{array}$ & $\begin{array}{l}\text { Larger marker sets } \\
\text { Population genomics } \\
\text { Gene expression studies } \\
\text { Multispecies approaches } \\
\text { Seascape genetic approaches }\end{array}$ \\
\hline Hybridization & $\begin{array}{l}\text { Larger marker sets } \\
\text { Hybridization genomics } \\
\text { Candidate genes for reproductive isolation } \\
\text { Gene expression studies }\end{array}$ \\
\hline Ecology & $\begin{array}{l}\text { Demographic estimate accuracy } \\
\text { Genetic basis of sexual traits and signaling } \\
\text { Movement and local adaptation } \\
\text { Genetics of adaptation }\end{array}$ \\
\hline Conservation & $\begin{array}{l}\text { Higher accuracy molecular assignments } \\
\text { Functional differences between populations } \\
\text { (gene expression) } \\
\text { Disease screening, toxicology }\end{array}$ \\
\hline
\end{tabular}

variation in a number of taxa (e.g. McCracken et al. 2009, Sætre \& Sæther 2010, Schluter et al. 2010) including seabirds (e.g. Baião et al. 2007).

Advances in other taxa are highlighting key areas of research relevant to the study of seabird evolution and ecology, particularly advances in avian model systems like the Ficedula flycatchers (Sætre \& Sæether 2010). Thus, research is coming full-circle, with molecular studies providing insight into the genetic basis of morphological and behavioural characters that were once used to infer the genetic relationships among populations and species. As sequencing technology improves and costs decrease, the development of genomic resources for seabirds will also play an increasing role in seabird conservation (Frankham 2010). These advances are particularly timely, as many species are listed as threatened or endangered, global fish stocks continue to decline, and numerous, generally unknown, consequences of climate change are set to impact many seabirds (Grémillet \& Boulinier 2009).

Here we review molecular genetic methods for studying seabird evolution and ecology, and then

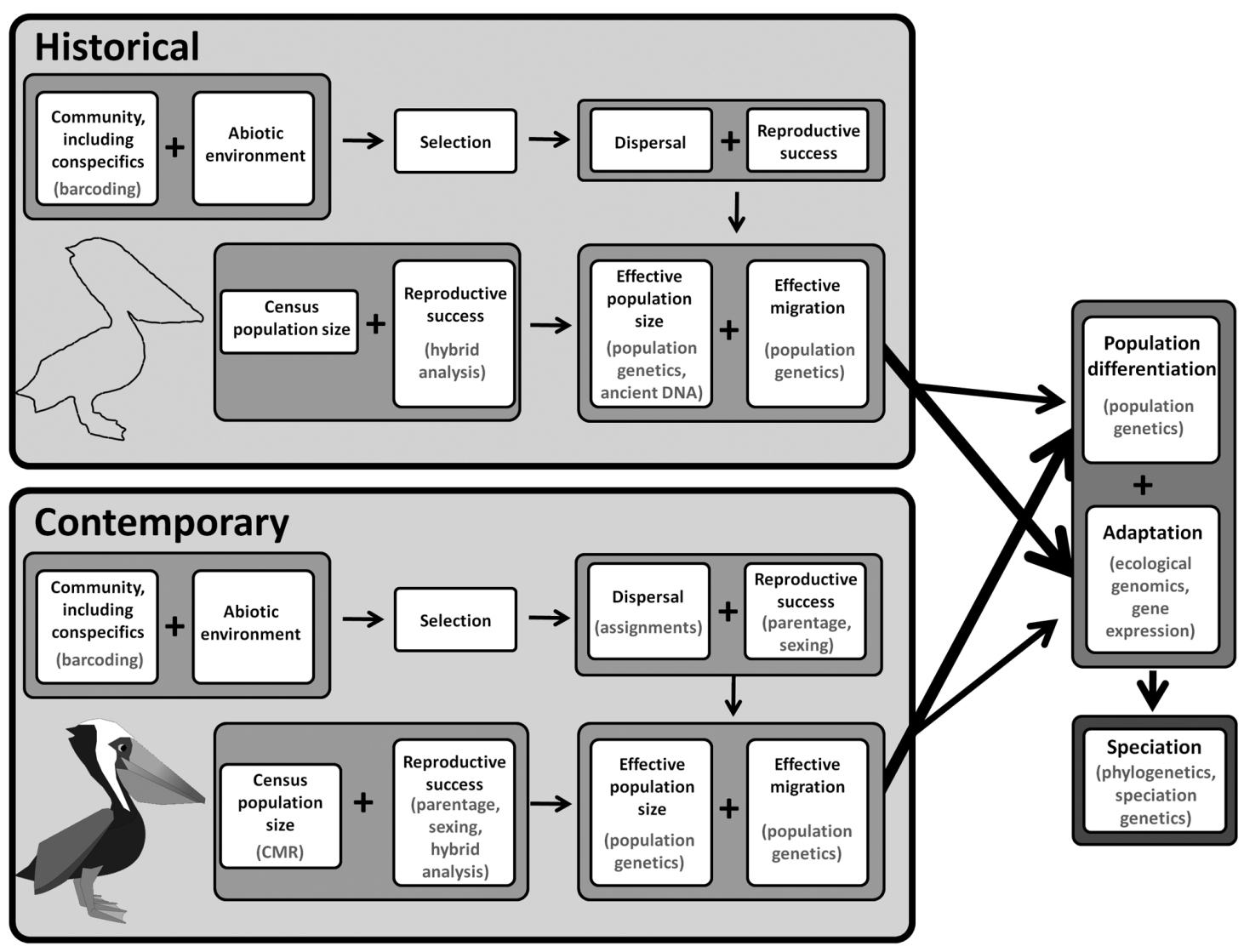

Fig. 1. Applications of molecular tools (in parentheses) for the study of seabird evolution and ecology. Arrow thickness indicates the presumed strength of causal relationships 
Table 4. Types of molecular markers used in studies of evolution and ecology, the source of genetic variation, potential uses, and costs of analysis; devel.: development; screen.: screening; mod.: moderate

\begin{tabular}{|c|c|c|c|c|c|}
\hline Marker type & Source of variation & Uses & $\begin{array}{c}\text { Cost } \\
\text { (devel.) }\end{array}$ & $\begin{array}{c}\text { Cost } \\
\text { (screen.) }\end{array}$ & Notes \\
\hline \multicolumn{6}{|l|}{ mtDNA } \\
\hline $\begin{array}{l}\text { Restriction } \\
\text { fragment length } \\
\text { polymorphism } \\
\text { (RFLP) }\end{array}$ & $\begin{array}{l}\text { Lengths of fragments due } \\
\text { to substitutions at } \\
\text { restriction sites and in } \\
\text { intervening sequences }\end{array}$ & $\begin{array}{l}\text { Population genetics, } \\
\text { phylogenetics }\end{array}$ & Low & Mod. & $\begin{array}{l}\text { Superseded by direct sequencing } \\
\text { (see following marker type) }\end{array}$ \\
\hline Direct sequencing & Any mutation & $\begin{array}{l}\text { Population genetics, } \\
\text { hybridization, phylo- } \\
\text { genetics }\end{array}$ & Low & Low & $\begin{array}{l}\text { Inferences restricted by unusual } \\
\text { inher-itance (matrilineal, no } \\
\text { recombination), but high } \\
\text { mutation rate makes it useful for } \\
\text { recent and/or rapid evolution } \\
\text { events }\end{array}$ \\
\hline \multicolumn{6}{|l|}{ Nuclear DNA } \\
\hline $\begin{array}{l}\text { Minisatellite DNA } \\
\text { (classical finger- } \\
\text { printing) }\end{array}$ & $\begin{array}{l}\text { Numbers of repeat units } \\
\text { within a fragment }\end{array}$ & $\begin{array}{l}\text { Kinship, individual } \\
\text { identification }\end{array}$ & Low & Mod. & $\begin{array}{l}\text { Superseded by use of } \\
\text { microsatellite DNA }\end{array}$ \\
\hline $\begin{array}{l}\text { Randomly } \\
\text { amplified } \\
\text { polymorphic DNA } \\
\text { (RAPD) }\end{array}$ & $\begin{array}{l}\text { Presence/absence of frag- } \\
\text { ments due to substitutions } \\
\text { in PCR priming sites and } \\
\text { intervening sequences }\end{array}$ & $\begin{array}{l}\text { Kinship, population } \\
\text { genetics }\end{array}$ & Low & Low & $\begin{array}{l}\text { Repeatability tends to be poor; } \\
\text { some journals will not accept } \\
\text { RAPD data; dominant inheritance } \\
\text { complicates some inferences }\end{array}$ \\
\hline $\begin{array}{l}\text { Amplified } \\
\text { fragment length } \\
\text { polymorphism } \\
\text { (AFLP) }\end{array}$ & $\begin{array}{l}\text { Presence/absence of } \\
\text { fragments due to } \\
\text { substitutions in PCR } \\
\text { priming sites, restriction } \\
\text { sites, and intervening } \\
\text { sequences }\end{array}$ & $\begin{array}{l}\text { Population genetics, } \\
\text { hybridization }\end{array}$ & Low & Low & $\begin{array}{l}\text { Dominant inheritance } \\
\text { complicates some inferences }\end{array}$ \\
\hline $\begin{array}{l}\text { Microsatellite } \\
\text { DNA; intersimple } \\
\text { sequence repeat } \\
\text { (ISSR), short } \\
\text { tandem repeat } \\
\text { (STR) }\end{array}$ & $\begin{array}{l}\text { Numbers of repeat units } \\
\text { within a fragment }\end{array}$ & $\begin{array}{l}\text { Kinship, population } \\
\text { genetics, } \\
\text { hybridization }\end{array}$ & Mod. & Low & $\begin{array}{l}\text { Widely used, but becoming } \\
\text { superseded by direct sequencing; } \\
\text { vulnerable to homoplasy }\end{array}$ \\
\hline $\begin{array}{l}\text { Single nucleotide } \\
\text { polymorphisms } \\
\text { (SNPs) }\end{array}$ & $\begin{array}{l}\text { Any mutation, but usually } \\
\text { a substitution }\end{array}$ & $\begin{array}{l}\text { Potential kinship via } \\
\text { phylogenetics, but } \\
\text { usually population } \\
\text { genetics, } \\
\text { hybridization }\end{array}$ & $\begin{array}{l}\text { High at } \\
\text { present }\end{array}$ & Low & $\begin{array}{l}\text { Highly repeatable; source of } \\
\text { variation is usually known }\end{array}$ \\
\hline Direct sequencing & $\begin{array}{l}\text { Any mutation, but usually } \\
\text { a substitution }\end{array}$ & $\begin{array}{l}\text { Population genetics } \\
\text { and phylogenetics, } \\
\text { but also kinship, } \\
\text { hybridization }\end{array}$ & Low & $\begin{array}{l}\text { Mod. at } \\
\text { present }\end{array}$ & $\begin{array}{l}\text { Highly repeatable; source of } \\
\text { variation is usually known; } \\
\text { screening cost is decreasing } \\
\text { rapidly }\end{array}$ \\
\hline
\end{tabular}

draw examples from studies of phylogenetics, population genetics, hybridization and ecology (Table 3, Fig. 1). For each section, we outline traditional approaches, highlight examples using new molecular tools, and explore how traditional and molecular methods can be combined. We also give an overview of applications of molecular methods to conservation. This paper is not a comprehensive review of all molecular genetic work currently being conducted on seabirds; it is meant to highlight a few areas of research and to expose some ideas about future directions in seabird research.

\section{MOLECULAR GENETIC METHODS}

Information about an organism's evolution and ecology is retained in its DNA, and recent methods, especially those based on coalescent theory and Bayesian statistics, let us extract and understand this information. Numerous methods have been developed to assay DNA variation indirectly (several recent reviews, e.g. Baker 2000, Avise 2004; Table 4). One of the earliest methods to be developed was DNA fingerprinting, in which restriction enzymes (bacterial enzymes that recognize and cut short frag- 
ments of DNA, typically 4 to 6 base pairs [bp] long) and agarose gel electrophoresis are used to screen individuals for variation in the number of repeats of a 20 to 25 bp unit. Restriction enzymes also can be used to detect mutations resulting in restriction fragment length polymorphisms (RFLPs) in short fragments of purified DNA such as mitochondrial DNA (mtDNA). These methods of mutation detection have been largely superseded by tools based on polymerase chain reaction (PCR), or DNA amplification. Common techniques include analysis of amplified fragment length polymorphisms (AFLPs), which uses a combination of restriction enzymes and PCR to detect sequence variation, and microsatellite analyses, which use specially designed PCR primers to amplify gene regions that tend to vary in the number of short (typically 2 to $6 \mathrm{bp}$ ) repeating units (Table 4).

Indirect methods of mutation detection such as AFLPs and microsatellite screening have the advantage that large numbers of individuals can be assayed quickly and relatively inexpensively. However, these tools are being replaced by direct sequencing of target genes, and analyses of single nucleotide polymorphisms (SNPs - single base pair replacements, insertions or deletions; Vignal et al. 2002, Coates et al. 2009). New sequencing methods are making SNP discovery and direct sequencing much easier and will greatly increase genetic tools for seabird studies (our Table 1; Tautz et al. 2010, Helyar et al. 2011). Financial costs of generating and mapping genomic level SNP datasets, or of identifying variable microsatellites are no longer prohibitive (see reviews by Hudson 2008, Shendure \& Ji 2008, Tautz et al. 2010). Numerous studies of seabird evolution and ecology have used DNA sequencing to assess phylogenetic relationships (e.g. Pereira \& Baker 2008, Jesus et al. 2009, Patterson et al. 2011), population differentiation (e.g. Morris-Pocock et al. 2008, Gómez-Díaz et al. 2009, Hailer et al. 2011; see review by Friesen et al. 2007b) and hybridization (e.g. Pacheco et al. 2002, Gay et al. 2007, 2008b, Taylor et al. 2010b), and to estimate population parameters such as migration rates or population sizes (e.g. Boessenkool et al. 2010). New sequencing methods now enable whole genomes to be sequenced within months (Hudson 2008, Mitchell-Olds et al. 2008, Shendure \& Ji 2008, Thomson et al. 2010, Ekblom \& Galindo 2011), although the full genome of a seabird species has yet to be assembled. The potential for genomic level seabird research to contribute to the larger picture in evolutionary biology is huge, particularly given recent findings regarding population divergence, hybridization, and speciation in a num- ber of seabird species (see 'Population genetics and phylogeography' and 'Hybridization' below).

The drawbacks associated with using molecular genetic tools for studying ecology and evolution are rapidly being overcome (Hudson 2008). Previously, molecular genetic tools could be slow and expensive to adapt to particular research projects, and they often provided little information about functional variation or behaviour (but see e.g. Baião et al. 2007, McCracken et al. 2009). Until recently, assembling enough variable markers was also difficult for numerous seabird species: traditional, first generation sequencing methods suggested that variable markers are less common in birds than in other taxa (Baker 2000). New sequencing methods (summarized in Table 1; see reviews by Schuster 2008, Shendure \& Ji 2008) are revolutionizing the study of ecology and evolution and have essentially removed the limitations outlined here (Hudson 2008, Tautz et al. 2010, Gardner et al. 2011); generating large, variable SNP or microsatellite datasets is now a possibility for any species. Additionally, the development of large genomic resources for seabirds will allow more directed studies that can target genes responsible for functional variation and possibly even the genetic underpinnings of behaviour, as has been done in other groups of organisms (Barrett 2010, Hubbard et al. 2010, Stapley et al. 2010, Toth et al. 2010).

Coalescent-based approaches that utilize Markov chain Monte Carlo (MCMC) methods and likelihoodbased inference (implemented in Isolation with Migration: IM, Isolation with Migration Analytic: IMa, and Isolation with Migration Analytic 2: IMA2; see Table 2), and, more recently, approaches utilizing Approximate Bayesian Computation ( $\mathrm{ABC}_{\text {; }}$ Cornuet et al. 2008) (Table 2) are rapidly increasing our ability to robustly evaluate hypotheses about population divergence, and to infer population history (Hey 2006, Hey \& Nielsen 2007, Csilléry et al. 2010, Lopes \& Beaumont 2010, Pinho \& Hey 2010). These approaches allow us to robustly estimate divergence times, historical and contemporary population sizes, rates of gene exchange during divergence, and to evaluate competing divergence scenario hypotheses. A number of seabird research groups are now utilizing larger (10+ markers) datasets and have recently developed analytical methods (Peucker et al. 2009, Lopes \& Boessenkool 2010, Morris-Pocock et al. 2010, 2011, Taylor et al. 2011a, Welch et al. 2011).

DNA-based investigations of seabird evolution and ecology have the greatest power when combined with traditional methods, for example, by comparing variation in AFLPs with band returns to infer meta- 
Table 5. Examples of studies in which molecular data were combined with other types of data to enable new insights into seabird evolution, ecology or conservation. AFLP: amplified fragment length polymorphism

\begin{tabular}{|c|c|c|c|c|}
\hline Species & $\begin{array}{l}\text { Molecular } \\
\text { marker(s) }\end{array}$ & $\begin{array}{l}\text { Additional } \\
\text { tool(s) }\end{array}$ & Inference & Source \\
\hline $\begin{array}{l}\text { Cory's shearwater } \\
\text { Calonectris diomedea }\end{array}$ & Microsatellites & $\begin{array}{l}\text { Morphometrics, } \\
\text { stable isotopes, } \\
\text { trace metals }\end{array}$ & $\begin{array}{l}\text { Individuals could be assigned to } \\
\text { breeding colonies with } 86 \% \text { accuracy }\end{array}$ & $\begin{array}{l}\text { Gómez-Díaz \& } \\
\text { González-Solís (2007) }\end{array}$ \\
\hline Procellariiformes & $\begin{array}{l}\text { Allozyme, DNA- } \\
\text { DNA hybridiza- } \\
\text { tion, DNA } \\
\text { sequence }\end{array}$ & $\begin{array}{l}\text { Morphology, } \\
\text { behaviour, life } \\
\text { history }\end{array}$ & $\begin{array}{l}\text { More comprehensive inclusion of } \\
\text { species than in previous phylogenies }\end{array}$ & $\begin{array}{l}\text { Kennedy \& Page } \\
(2002)\end{array}$ \\
\hline Phalacrocoracidae & mtDNA & Osteology & $\begin{array}{l}\text { Cliques' of compatable characters } \\
\text { suggest similar selective pressures }\end{array}$ & Holland et al. (2010) \\
\hline $\begin{array}{l}\text { Atlantic puffin } \\
\text { Fratercula arctica }\end{array}$ & Allozymes & Morphometrics & $\begin{array}{l}\text { Geographic variation in body size is } \\
\text { due to environmental effects }\end{array}$ & Moen (1991) \\
\hline $\begin{array}{l}\text { Band-rumped storm- } \\
\text { petrel Oceanodroma } \\
\text { castro }\end{array}$ & $\begin{array}{l}\text { mtDNA, } \\
\text { microsatellites }\end{array}$ & $\begin{array}{l}\text { Morphometrics, } \\
\text { vocalizations }\end{array}$ & $\begin{array}{l}\text { Divergence in morphology and } \\
\text { vocalizations of seasonal populations } \\
\text { precedes divergence in neutral } \\
\text { molecular markers }\end{array}$ & $\begin{array}{l}\text { Smith \& Friesen } \\
(2007), \text { Bolton et al. } \\
(2008), \text { Deane (2011) }\end{array}$ \\
\hline $\begin{array}{l}\text { Black-legged } \\
\text { kittiwake Rissa } \\
\text { tridactyla }\end{array}$ & Microsatellites & $\begin{array}{l}\text { Microsatellite } \\
\text { variation in ticks }\end{array}$ & $\begin{array}{l}\text { Kittiwakes prospecting among local } \\
\text { colonies results in gene flow for } \\
\text { kittiwakes but not ticks }\end{array}$ & McCoy et al. (2005b) \\
\hline $\begin{array}{l}\text { Wandering albatross } \\
\text { Diomedea exulans }\end{array}$ & AFLP & Band returns & $\begin{array}{l}\text { Populations are demographically but } \\
\text { not genetically isolated }\end{array}$ & Milot et al. (2008) \\
\hline $\begin{array}{l}\text { Laysan albatross } \\
\text { Phoebastria } \\
\text { immutabilis }\end{array}$ & $\begin{array}{l}\text { mtDNA, } \\
\text { microsatellites }\end{array}$ & Band returns & $\begin{array}{l}\text { Rare migration prevents genetic } \\
\text { divergence of populations and enables } \\
\text { colonization of new sites despite } \\
\text { generally strong philopatry }\end{array}$ & Young (2010) \\
\hline $\begin{array}{l}\text { Cook's petrel } \\
\text { Pterodroma cookii }\end{array}$ & mtDNA & $\begin{array}{l}\text { Light-based } \\
\text { data loggers, } \\
\text { stable isotopes }\end{array}$ & $\begin{array}{l}\text { Genetic divergence between colonies } \\
\text { is ultimately the result of differences in } \\
\text { non-breeding distributions and } \\
\text { breeding times }\end{array}$ & Rayner et al. (2011) \\
\hline $\begin{array}{l}\text { Glaucous-winged gull } \\
\text { Larus occidentalis } \\
\text { and western gull } \\
\text { Larus glaucescens }\end{array}$ & $\begin{array}{l}\text { mtDNA } \\
\text { microsatellites }\end{array}$ & $\begin{array}{l}\text { Plumage } \\
\text { colouration } \\
\text { Bare-part } \\
\text { colouration }\end{array}$ & $\begin{array}{l}\text { Restricted introgression of phenotypic } \\
\text { traits compared to neutral markers - } \\
\text { indicating selection on phenotypic } \\
\text { traits and a role in isolation the species }\end{array}$ & Gay et al. (2008) \\
\hline
\end{tabular}

population dynamics (e.g. Milot et al. 2008), by combining morphometrics with isotope and genetic data to assign birds killed during winter to breeding populations for impact assessment (e.g. Gómez-Díaz \& González-Solís 2007), or by using tracking data in concert with genetic estimates of gene flow in investigations of mechanisms of population differentiation (detailed in 'Ecology' below and in Table 5).

\section{PHYLOGENETICS}

Phylogenetics, the study of the evolutionary relationships among organisms, attempts to construct a tree that is representative of the true evolutionary history of a group of organisms. The tree can then aid investigations of taxonomy, character evolution (e.g. mating rituals, or clutch size) and diversification (e.g. mechanisms of speciation; Avise 2004). However, unless the phylogenetic relationships among species are well resolved, evolutionary hypotheses cannot be reliably tested.

Traditional methods for phylogenetic reconstruction for seabirds rely on external and internal morphology, behaviour, and fossils. Studies based on these methods have provided significant insights into seabird evolution and ecology. For example, behavioural characters, morphology, osteology and allozymes have been used to evaluate evolutionary relationships within the Alcidae, Stercorariidae and Pelecaniformes (van Tets 1965, Strauch 1985, Watada et al. 1987, Kennedy et al. 1996, Chu et al. 2009, Smith 2010). However, the genetic basis for these characters is not usually known, and morphology and behaviour may differ between populations because of selection, phenotypic plasticity, or environmental 
Fig. 2. Phylogenetic tree for the Sulidae (a) based on a fragment of the cytochrome $b$ gene (gene tree) modified from Friesen \& Anderson (1997), and (b) based on multiple nuclear introns (d-crystallin intron7, a-enolase intron 8 , ornithine decarboxylase introns 6 and 7, triosephosphate isomerase intron 4, and lipoprotein lipase intron 2) and one mitochondrial marker (cytochrome b) modified from Patterson et al. (2011). Node support and branch lengths have been removed for simplicity, but are high throughout a

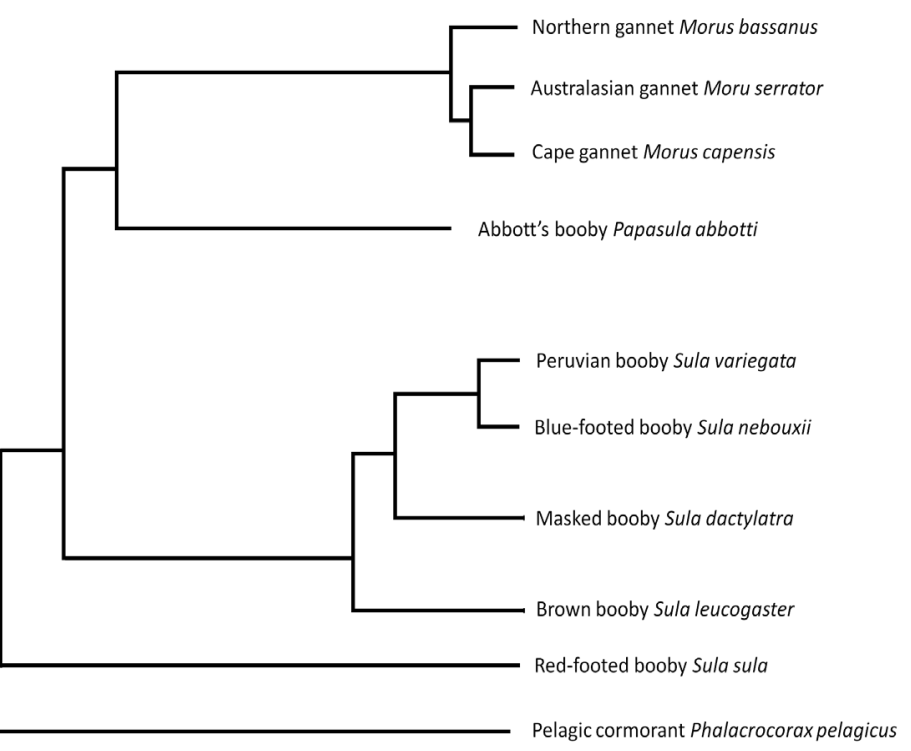

b

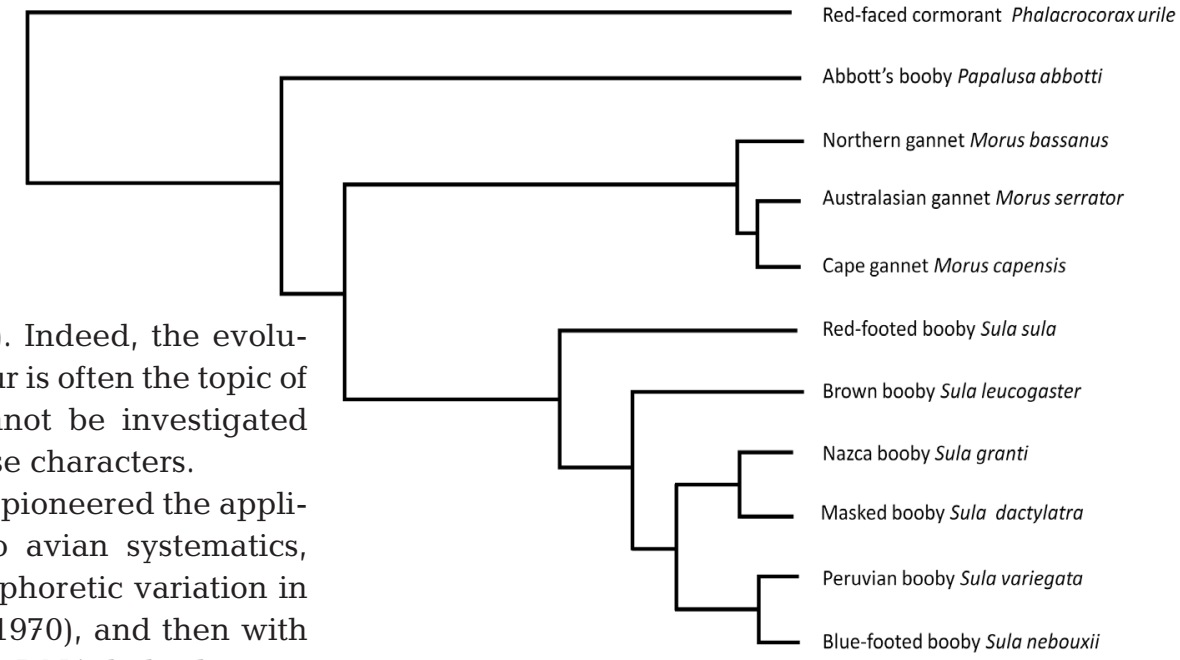

isms, because single-gene trees do not necessarily represent the species' true history (Maddison 1997, Degnan \& Rosenberg 2006, 2009). Recent advances in sequencing technology have allowed researchers to expand genetic datasets, and developments in phylogenetic analyses now allow researchers to estimate species trees using coalescent theory and Bayesian statistics (Table 2; e.g. Bayesian Estimation of the Species Tree [BEST], Liu 2008). These advances together led to the Tree of Life web project, which started in 1996, but has since expanded with these advances (Maddison \& Maddison 1996).

Several recent phylogenetic studies of seabirds illustrate the utility of multilocus datasets. For example, Abbott's booby Papasula abbotti is ecologically, morphologically, and behaviourally distinct from other species in the Sulidae (Nelson 1978), and its placement within the family was unclear until recently. resent the evolutionary relationships among organ- 
Patterson et al. (2011) used 5 nuclear introns and a mitochondrial marker to estimate a species tree using BEST (Fig. 2b). They found that Abbott's booby was basal to all other members of the Sulidae and likely diverged from the group about 22 million years ago. Interestingly, the results were broadly congruent with van Tets (1965) phylogenetic reconstruction based on behaviour.

In a similar study, Kennedy et al. (2009) used multiple unlinked loci to evaluate the phylogenetic position of the Galapagos cormorant Phalacrocorax harrisi, an ecologically and morphologically unique member of the Phalacrocoracidae. Although this species is the only phalacrocoracid that has lost the ability to fly and was previously placed in its own genus, results from Kennedy et al. (2009) indicate that the Galapagos cormorant is most closely related to 2 species that are common and broadly distributed in North America: the double-crested cormorant $P$. auritus and the neotropic cormorant $P$. brasilianus.

Kennedy \& Page's (2002) procellariiform phylogeny provides an excellent example of synergy through the combination of different analytical approaches. These authors used 7 incomplete phylogenies based on behaviour, DNA-DNA hybridization, isozymes, life history, morphology, and DNA sequence data to generate a supertree for the Procellariiformes. In another example, Holland et al. (2010) compared strongly supported but incongruent trees based on osteological versus molecular data for the cormorants and shags. Their study found 'cliques' of compatible morphological characters, suggesting groups of taxa under similar selective pressures. Although Cohen et al. (1997) provided a discussion of difficulties in combining morphological, behavioural, and genetic data to construct phylogenies, future researchers should attempt to construct phylogenies based on multiple nuclear and mitochondrial loci and, ideally, combine traditional approaches in phylogeny construction. Studies such as these are needed for other groups of seabirds, and will aid future investigations of both character evolution and mechanisms of diversification in seabirds.

\section{POPULATION GENETICS AND PHYLOGEOGRAPHY}

Understanding population genetic structure (the extent to which local populations differ genetically) helps researchers understand many aspects of evolution and ecology (Fig. 1). For example, some seabird species exhibit dramatic geographic variation in morphology and behaviour while others do not (e.g.
Storer 1952, Ainley 1980, Power \& Ainley 1986, del Hoyo et al. 1992, 1996, Baião et al. 2007). Examining population genetic structure in these species can help determine the adaptive significance (if any) of geographic variation in life history, morphology, physiology and behaviour; how, where and why the variation originated; how populations are connected or what prevents them from being connected; and how species multiply. Furthermore, population differentiation is the first step towards speciation in most speciation models (Coyne \& Orr 2004). Consequently, many population genetic studies explore the evolutionary histories of seabirds to understand the speciation history. A subfield of population genetics, phylogeography, studies the correspondence between phylogeny and geography, and can provide insights into evolution and ecology (Avise et al. 1987, Avise 1994).

Studies of morphology, physiology, and behaviour help elucidate population genetic structure. For example, geographic variation in plumage and morphometrics is more extensive in Cepphus spp. (guillemots) than in Uria spp. (murres). Storer (1952) proposed that this difference is a result of differences in dispersal: guillemots nest in small colonies distributed linearly along coastlines and probably do not disperse far from colonies during the non-breeding season, whereas murres nest in a small number of large colonies, and generally migrate seasonally. However, as in phylogenetic studies, the genetic basis of morphological and behavioural characters is not usually known (but see Baião et al. 2007): even if individuals or populations are morphologically similar, they may differ genetically (e.g. Friesen et al. 1996a, Morris-Pocock et al. 2008, Hailer et al. 2011).

Protein electrophoresis also has provided useful insights into population structure and evolution (Baker 2000, Avise 2004). For example, protein variation suggests that thick-billed murres Uria lomvia form kin groups within colonies (Friesen et al. 1996b). In contrast, Moen (1991) found little geographic variation in allozymes among Atlantic puffins from throughout the northeast Atlantic, despite significant variation in body size. Protein electrophoresis yields data rapidly and is inexpensive to conduct; however, birds must be captured and sometimes sacrificed, proteins degrade easily, protein variability is often insufficient to be useful, and some variation is under selection (potentially violating assumptions of neutral mutation theory) and thus may not reflect true evolutionary history (Baker 2000).

Initial uses of DNA to study seabird population differentiation focused on mtDNA (e.g. Pitocchelli et al. 1995), because its unusual mode of inheritance and 
relatively high mutation rate make it sensitive to changes in population size and migration rate (Wilson et al. 1985, Baker 2000, Avise 2004, Eda et al. 2008, Rains et al. 2011). Increasingly however, studies of population differentiation, phylogeography, and speciation are using large multilocus datasets of SNPs, microsatellites and sequence data (Table 3) to provide a more complete picture of contemporary versus historical population sizes and dispersal rates (Fig. 1; e.g. Peery et al. 2010, Hailer et al. 2011). For example, Techow et al. (2010) used cytochrome $b$ and 6 microsatellite loci to examine the phylogeography and speciation history of giant petrels Macronectes spp. Their analyses revealed a complex history that involved population fragmentation, periods of population expansion, and secondary contact.

Population genetic analyses of seabirds have also benefitted from multispecies approaches, at both the seabird (i.e. analyzing multiple species of seabirds) and organismal (i.e. analyzing multiple species of seabird and other non-avian taxa) levels (e.g. parasites). Parasites are useful for studying long-lived species such as seabirds (Nieberding \& Olivieri 2007), and multispecies approaches utilizing parasites have increased our understanding of the constraints on the genetic structure and the movements of seabirds (e.g. McCoy et al. 2005b, Gómez-Díaz et al. 2007). McCoy et al. (2005b) compared population genetic structure in black-legged kittiwakes Rissa tridactyla with one of their ectoparasites (the tick Ixodes uriae). Population genetic structure was much stronger in the ticks than in the kittiwakes, and, given the life history of the ticks, McCoy et al. (2005b) inferred that local movements of kittiwakes during the breeding season result in gene flow for the kittiwakes but not the ticks. Similarly, multispecies approaches at the seabird level have allowed researchers to detect common factors responsible for the presence or absence of population structure (important for making predictions for unstudied species, or informing conservation decisions) (reviewed in Friesen et al. 2007b), and the potential for multispecies approaches is very high given the aforementioned advances in sequencing technology and data analysis techniques.

The strongest population genetic and phylogeographic seabird studies are synergistic and combine molecular data with demographic data, morphology, and/or behaviour to elucidate mechanisms of population differentiation in seabirds. Our goal should be combining this approach with larger, more robust genetic datasets, as some researchers are doing already - though not yet at the scale made possible by new sequencing methods. For example, by comparing variation in AFLPs with band returns, Milot et al. (2008) showed that populations of wandering albatrosses Diomedea exulans are demographically but not genetically isolated. In another synergistic study, Rayner et al. (2011) used geolocator-based tracking, isotopes, and DNA-based methods to examine contemporary and historical populations of Cook's petrel Pterodroma cookii, reporting that genetically distinct populations are segregated during the non-breeding season. They suggested that habitat specialization during the non-breeding season may lead to breeding asynchrony, which may restrict gene flow between the populations in conjunction with philopatry (Rayner et al. 2011).

Further studies such as these are needed to understand mechanisms of diversification and adaptation in seabirds, especially in relation to anthropogenic disturbances such as climate change. We see an opportunity for seabird evolutionary biologists and ecologists to move from population genetic to population genomic level studies (Hudson 2008, Tautz et al. 2010, and see Viner \& Mitchell 2010 entire issue). Larger, more robust genetic datasets, combined with the ecological knowledge of many seabird researchers, will make population genomic studies more informative as they relate to the mechanisms that generate seabird diversity, than present population genetic studies. The possibility of expanding analyses to examine genes responsible for divergence or to explore differences in gene expression (transcriptomics) between closely related species (e.g. physiological differences, Hedgecock et al. 2007), should be pursued by seabird researchers, especially given the extreme physiology of this taxonomic group and the potential importance of physiological differences in relation to divergence events. These avenues of inquiry will contribute more generally to our understanding of population divergence and speciation and be valuable to the broader evolutionary biology community.

Recently, the term 'seascape genetics' has been used to describe population genetic studies of marine organisms that examine how environmental variables (e.g. ocean currents, ocean productivity) influence differentiation (e.g. Skillings et al. 2011, Amaral et al. 2012, see review by Selkoe et al. 2008; the terrestrial equivalent, 'landscape genetics', is reviewed in Sork \& Waits 2010; see also Special issue on landscape genetics Vines \& Mitchell 2010). Although no seabird studies to date have explicitly used the term 'seascape genetics', seabird researchers are generally cognizant of the effects of oceanic environmental variables such as fronts, eddies, and climatic phe- 
nomena like El Niño on seabird population genetics (Steeves et al. 2003, 2005a,b, Morris-Pocock et al. 2008, Hailer et al. 2011, Rayner et al. 2011, Taylor et al. 2011a). Future population genetic studies of seabirds would benefit from including these variables explicitly, to ensure seabird population genetic studies remain on par with studies of other marine organisms.

\section{HYBRIDIZATION}

Hybridization can be either a creative or a destructive force in evolution (Harrison 1993, Allendorf et al. 2001). Global rates of hybridization are increasing and have contributed to species extinctions in a number of taxonomic groups, but have led to the establishment of new species in others (Brumfield 2010). Regardless of the outcome, documenting hybridization and understanding how it affects seabirds is an important aspect of seabird ecology and evolution, but is potentially erroneous without data from multiple, unlinked genetic markers. Hybridization also has conservation implications. For example, as climate change alters marine habitats a number of temperate seabird species may expand their ranges towards the poles. The evolutionary and conservation implications of these range shifts are unknown; however, studies of other species suggest that range shifts may increase hybridization rates (Kelly et al. 2010).

Traditional studies of hybridization in seabirds involved reports of birds with unusual plumage patterns (e.g. Cairns \& DeYoung 1981), or geographic variation in morphology and/or allozyme allele frequencies (e.g. Bell 1996). These studies are complicated by the fact that back-cross hybrids, and even F1 hybrids, can be difficult to distinguish from parental species based on morphology (e.g. Friesen et al. 1993). Researchers now have the ability to generate sufficiently large genetic datasets (see above; Table 1) and possess appropriate computer programs to characterize hybridization between species thoroughly (see 'Molecular genetic methods' above and the following paragraph; Table 2; Gay et al. 2007, 2008, 2009, Taylor et al. 2010a, 2011b).

Although hybridization is generally considered rare in seabirds, an increasing number of studies are documenting hybridization and interspecific gene flow using multilocus cline and coalescent-based analyses (e.g. Reinhardt et al. 1997, Gay et al. 2007, 2008, Brown et al. 2010, Carneiro et al. 2010, Taylor et al. 2010b, 2011b, Taylor 2011). Molecular markers can also aid in determining whether an individual has hybrid ancestry, how many generations ago hybridization occurred, and which species was maternal vs. paternal. Several recent studies of seabird hybridization illustrate the utility of using molecular markers.

An example comes from Taylor's (2011) analysis of hybridization between blue-footed boobies Sula nebouxii and Peruvian boobies Sula variegata. Taylor (2011) used a multilocus data set and cline analysis to examine introgression and to characterize the hybrid zone. He found that blue-footed and Peruvian boobies hybridize, but that pre- and postzygotic barriers are well established, particularly in light of the recent divergence of this species pair (Patterson et al. 2010). Additionally, Taylor et al. (2010b) and Taylor (2011) used a multilocus dataset to determine that morphologically aberrant individuals within the hybrid zone are most likely first generation hybrids and that the majority of hybridization between bluefooted and Peruvian boobies takes place between female Peruvian boobies and male blue-footed boobies, with subsequent backcrossing primarily between female hybrids and male blue-footed boobies. Finally, Taylor (2011) evaluated the likelihood that this species pair diverged from their common ancestor with gene flow, and found that a divergence with gene flow scenario was more likely than divergence without gene flow, using the isolation with migration model implemented in IMa. A dataset generated using new sequencing methods would significantly improve the ability of any study similar to the one completed by Taylor (2011) to explore the evolutionary history of a species pair, particularly given the low level of genomic divergence detected in this other studies using the current datasets.

A synergistic investigation of seabird hybridization was conducted successfully by Gay et al. (2007, 2008, 2009). They used multiple unlinked genetic markers, morphological characters, and cline analyses to determine the nature of the hybrid zone for each species pair. White-headed gulls appear more prone to hybridization than most other seabirds, possibly because of recent divergence and subsequent secondary contact between morphologically and behaviourally similar species (discussed in Gay et al. 2007, 2008, 2009). Gay and colleagues were able to document introgression at neutral loci and subsequently compared the rate of introgression of neutral loci with phenotypic introgression. They inferred that selection against phenotypic introgression is strong in both hybrid zones, and that sexual selection may be important for maintaining the species barriers.

Seabird researchers interested in hybridization should take a synergistic approach whenever possi- 
ble. Future investigations of hybridization in seabirds will benefit from larger, genome-spanning datasets, and approaches that target functional differences between hybridizing species. As with hybrid-zone research on other non-model organisms, seabird researchers should seek to determine the genetic regions, and ultimately genes, responsible for reproductive isolation.

\section{ECOLOGY}

Tracking population fluctuations and dispersal patterns is important for understanding how species respond to natural and anthropogenic stressors. Such information is critical both for understanding ecology and evolution, and for conservation (see next section). Capture-mark-recapture (CMR) studies (banding or ringing) help to clarify population relationships and dynamics, and the technology required for banding studies is relatively cheap (e.g. Nisbet 1989, Wooller et al. 1992, Wanless et al. 2007). For example, a long-term banding study of blue-footed boobies Sula nebouxii on Isla Isabel, Mexico, revealed that individuals are more faithful to their first nest site than their natal site and may have a 'dispersal phenotype' (Kim et al. 2007). This behaviour is not shared by other members of the Sulidae and would not have been predicted based on long-term banding of the Nazca booby $S$. granti, a close relative of the blue-footed booby, in the Galapagos (Huyvaert \& Anderson 2004). Banding has also revealed long distance movement between seabird colonies and a general trend of natal philopatry in many seabirds (Wooller et al. 1992). More recently, GPS tracking has provided previously unattainable high-resolution data on seasonal and daily movements (Grémillet \& Boulinier 2009, Wilson \& Vandenabeele 2012, this Theme Section). Unlike banding, tracking studies require expensive equipment and have only recently become common in the literature. Both banding and tracking require extensive effort and are virtually impossible for secretive species.

DNA-based methods allow researchers to assign individuals to genetic populations and to estimate population parameters like dispersal and population size in non-invasive ways (e.g. using moulted feathers, fecal samples, scavenged carcasses). Most notably, molecular assignments can provide insights into movements with minimal disturbance to individuals. Molecular assignments involve using an individual's multilocus genotype to infer its origin (Manel et al. 2005). If an individual's genotype clusters with high probability with individuals from a different sampling site, that individual is likely a migrant. Molecular assignments are most successful when populations are significantly genetically differentiated (i.e. FST > 0.1) but can be used even when populations are only weakly differentiated (i.e. FST < 0.05) (e.g. Peery et al. 2008, Hall et al. 2009).

Although using molecular assignments to identify dispersal events can require large numbers of samples from many populations and so can be logistically challenging, this method is increasingly common in the seabird literature (e.g. Boessenkool et al. 2009, Schlosser et al. 2009) and often provides insights unavailable from banding data. Rare dispersal events, which are difficult to detect if band returns are low, may be captured in the multilocus genotype of an individual. For example, Boessenkool et al. (2009) used multilocus assignments in their study of yelloweyed penguins Megadyptes antipodes and found evidence of rare migration events that would not likely have been detected otherwise. Similarly, Hall et al. (2009) used molecular assignments to characterize dispersal patterns in marbled murrelets Brachyramphus marmoratus in central California, and Faria et al. (2010) used both molecular assignments and methods based on coalescent theory to infer sourcesink dynamics in South American terns Sterna hirundinacea. In an innovative modification of molecular assignments known as parent-offspring dyad analysis, Peery et al. (2008) determined that the central California population of marbled murrelets is a demographic sink.

Application of molecular assignments to species for which extensive CMR and/or tracking data exist is an especially promising but largely unused method to elucidate the connection between evolution and ecology, e.g. by disentangling the relative effects of historical versus contemporary seabird movements on local adaptation, or inferring the effect of nonbreeding distributions on population differentiation and speciation (Friesen et al. 2007b). For example, band returns indicate that Laysan albatrosses Phoebastria immutabilis are strongly philopatric to natal breeding colonies, making them highly vulnerable to anthropogenic disturbance. However, geographic variation in mtDNA and microsatellites suggests that Laysan albatrosses have sufficient dispersal over longer timeframes to maintain population genetic variation and enable rapid colonization (Milot et al. 2008, Young 2010, Rayner et al. 2011). We could not find any studies that combine data from molecular markers and satellite tracking, highlighting the need for research using this combination of methods. 
DNA-based methods allow seabird researchers to census populations through non-invasive molecular 'mark-and-recapture'. Rudnick et al. (2008) presented the method in their study of non-breeding imperial eagles Aquila heliaca in Kazakhstan. Direct counts of eagles in the Naurzum Zapovednik suggested that fewer than 32 individuals used the area; however, analysis of moulted feathers using the program MARK indicated a roosting population of 308 individuals (Rudnick et al. 2008). Although this approach has yet to be conducted on seabirds, the utility of the method and the nature of seabird roosting areas (numerous feathers available for sampling) suggest that it may be useful. Population sizes and changes in size can also be estimated indirectly by applying genetic theory to molecular variation. For example, deviations in heterozygosities from values predicted at mutation-drift equilibrium can be used to infer recent population increases or declines using programs such as BOTTLENECK (Cornuet \& Luikart 1996) and FLUCTUATE (Kuhner et al.1998). Using this approach, Birt et al. (2012) found support for census results suggesting that Xantus's murrelets Synthliboramphus hypoleucus hypoleucus on Guadalupe Island, Mexico, have declined over the last century, and by comparing variation in contemporary and historical samples of yellow-eyed penguins, Boessenkool et al. (2010) estimated an effective size an order of magnitude lower than the census size for the southern population than for the northern population.

Additionally, DNA-based methods allow the evaluation of sex-specific questions, since the sex of a bird can now be determined with relative ease, using only a blood or feather sample. Given that many seabirds are sexually monomorphic, and that morphological details are not always recorded during sample collection, molecular sexing of seabirds is invaluable. Indeed, a search of the literature highlights the prevalence of this method in recent years: over 400 papers on seabird ecology and evolution have used molecular sexing since 2002. The questions addressed by these studies are highly diverse and include investigations of physiological ecology (e.g. Giudici et al. 2010), breeding investment and foraging (e.g. Torres et al. 2011), sociochemical compounds (e.g. Leclaire et al. 2012), sex-specific foraging behaviour (e.g. Weimerskirch et al. 2006), disease transmission (e.g. Wojczulanis-Jakubas et al. 2011), and the utility of morphology or behaviour in sex determination of wild birds (Zavalaga et al. 2009).

Finally, DNA-based methods are useful for investigations of parentage and kinship in seabirds.
Microsatellites and SNPs can be used to generate genealogies, to detect extra pair paternity, and to assign offspring to adults when sampling is sufficient. The literature on this topic is vast and new sequencing methods will aid the development of the variable markers required for paternity assignment (e.g. Baião \& Parker 2009, Wojczulanis-Jakubas et al. 2009, Huyvaert \& Parker 2010).

\section{CONSERVATION}

In addition to providing managers with better understanding of seabird evolution and ecology, molecular genetic methods can aid conservation (recent reviews: Allendorf \& Luikart 2007, Frankham 2010, Haig et al. 2011). Probably the most important direct contribution at present involves defining units of conservation. To be most effective, species-level conservation must be based on sound taxonomy: failure to recognize reproductively isolated species can result in loss of diversity. Taxonomy was traditionally based on morphology and ecology, but recent studies have unveiled several examples of mistaken taxonomy such as 'cryptic' species that are similar in appearance and ecology but that represent reproductively isolated, sometimes ancient lineages (e.g. Friesen et al. 1996a, Bolton et al. 2008, Rayner et al. 2011). The New Zealand storm petrel Oceanites maorianus provides an example. Presumed extinct for 150 years, birds similar to the New Zealand storm petrel were documented off New Zealand in 2003. Analyses of variation in both mtDNA and a nuclear intron confirmed that these birds belonged to the same taxon as the type specimen and that represents a distinct species (Robertson et al. 2011).

In addition, most conservation legislation recognizes phenotypically, ecologically and/or genetically distinct populations of vertebrate species as worthy of protection (e.g. 'distinct population segments' under the US Endangered Species Act; 'diagnosable units' under the Canadian Species at Risk Act). The rationale is that loss of these populations would result in loss of some of the species' genetic resources, including potential local adaptations, and that such populations may be genetically and demographically isolated from each other. Distinct populations are often termed evolutionarily significant units (ESUs), and may be identified from unique molecular, morphological, behavioural or ecological characteristics (e.g. Moritz 1994, Fay \& Nammack 1996). Marbled murrelets illustrate the importance of defining distinct population segments. Murrelets breeding in 
Washington, Oregon and California were originally treated as a threatened population segment, distinct from British Columbia and Alaska birds (USFWS 1992), but when molecular studies failed to find genetic differences between these regions (Friesen et al. 2005), distinct population status was removed; the viability of the species is now being evaluated as a single unit.

Additionally, local populations may be demographically but not genetically isolated from each other. Such populations may have sufficient dispersal to prevent genetic differentiation and local adaptation, but not enough to function as a single demographic unit. Thus, birth rates, death rates, and other demographic parameters may differ. Such populations are often referred to as management units (MUs) and may be recognized from differences in allele frequencies at molecular markers (e.g. Moritz 1994). Results from molecular studies often provide insights not expected from ecological data. For example, the high dispersal ability of the yellow-eyed penguin Megadyptes antipodes suggests that the species represents a single demographic unit, but differences in frequencies of mitochondrial haplotypes and microsatellite alleles, and results of assignment tests indicate that birds breeding on New Zealand's South Island are demographically isolated from those elsewhere and should be treated as a separate MU (Boessenkool et al. 2009).

Molecular markers can also aid conservation. For example, estimates of effective population size are needed both to assign species to conservation categories and to develop recovery plans; these estimates are often one or more orders of magnitude lower than census sizes (e.g. yellow-eyed penguins; Boessenkool et al. 2010). Molecular markers can identify hybrid individuals and their descendants (see 'Hy. bridization' above), and so aid recovery plans by allowing managers to exclude hybrid individuals from captive breeding programs, or from the population if maintenance of genetically pure populations is a conservation goal (e.g. Haig et al. 2004). Population markers can also help to assess the population-specific effects of anthropogenic disturbances (e.g. oil spills, Riffaut et al. 2005; fisheries by-catch, Walsh \& Edwards 2005). Gómez-Díaz \& González-Solís (2007) provide an example of the synergistic application of molecular genetics with other tools for impact assessment. They were able to assign individual Calonectris spp. shearwaters that had been caught in long-line fisheries in the Mediterranean to their population of origin with 86 to $100 \%$ accuracy using morphometrics, stable isotopes, trace metals, and multilocus genotypes. As DNA technology becomes more accessible, many new applications to conservation are emerging (e.g. disease screening, Ishak et al. 2008; toxicology, Haig et al. 2011).

\section{CONCLUSIONS}

Studies of phylogenetics, population genetics, hybridization, speciation and ecology in seabirds have improved our understanding of evolution, ecology and conservation, and this can only grow as more seabird research groups incorporate DNAbased analyses including new sequencing technologies into their investigations. Seabird research in evolutionary biology has the potential to contribute in a significant way to evolutionary biology, given the ecological knowledge of seabird researchers, advances in sequencing technology and data analysis, and the fact that collection of a sufficient number of samples for robust genetic analyses is usually a possibility for colonially nesting organisms.

DNA-based methods are providing seabird researchers with tools to address previously intractable questions about seabird evolution and ecology. Although the majority of new genetic resources were not developed specifically for seabirds, advances in sequencing technology and analytical methods are resulting in improved genetic and genomic resources for seabirds within the capabilities of many seabird research groups. Many seabird researchers do not include genetic data in their studies; however genetics can provide versatile tools to aid in studying evolution, ecology and conservation of seabirds (Table 3, Fig. 1). Some molecular methods are still being optimized, but the potential applications of molecular markers will likely increase as DNA-marker generation becomes cheaper and faster, and methods of data interpretation become increasingly sophisticated. Results of studies that combine molecular markers with other tools will be especially useful to understanding the evolution, ecology and conservation not only of seabirds but also of other highly mobile organisms in a rapidly changing world.

Acknowledgements. We thank R. Wilson and G. Hunt for inviting this review and waiting patiently for its submission. M. Kennedy kindly shared unpublished data. T. Birt provided valuable comments on the manuscript. Thanks also to all members of the Friesen Lab, past and present, for their hard work and excellent contributions to the field. Funding was provided by NSERC (post-graduate scholarship to S.A.T.). 


\section{LITERATURE CITED}

Ainley D (1980) Geographic variation in Leach's storm petrel. Auk 97:837-853

Allendorf FW, Luikart G (2007) Conservation and the genetics of populations. Blackwell, Malden, MA

Allendorf FW, Leary RF, Spruell P, Wenburg JK (2001) The problem with hybrids: setting conservation guidelines. Trends Ecol Evol 16:613-622

Amaral AR, Beheregarat LB, Bilgman K, Boutov D and others (2012) Seascape genetics of a globally distributed, highly mobile marine mammal: the short-beaked common dolphin (Genus Delphinus). PLoS ONE 7:e31482

Anderson EC, Thompson EA (2002) A model-based method for identifying species hybrids using multilocus genetic data. Genetics 160:1217-1229

Ané C, Larget B, Baum DA, Smith SD, Rokas A (2007) Bayesian estimation of concordance among gene trees. Mol Biol Evol 24:412-426

Avise JC (1994) Molecular markers, natural history and evolution. Chapman \& Hall, New York, NY

Avise JC (2004) Molecular markers, natural history and evolution. Sinauer, Sunderland, MA

Avise JC, Arnold J, Ball RM, Bermingham E and others (1987) Intraspecific phylogeography: the mitochondrial DNA bridge between population genetics and systematics. Annu Rev Ecol Syst 18:489-522

Baião PC, Parker PG (2009) No evidence of extra-pair fertilization in red-footed boobies (Sula sula). Waterbirds 32: 179-182

Baião PC, Schreiber EA, Parker PG (2007) The genetic basis of the plumage polymorphism in red-footed boobies (Sula sula): a melanocortin-1 receptor (MC1R) analysis. J Hered 98:287-292

Baker AJ (2000) Molecular methods in ecology. Blackwell Science, Oxford

- Barbraud C, Weimerskirch H, Robertson GC, Jouventin P (1999) Size-related life history traits: insights from a study of snow petrels (Pagodroma nivea). J Anim Ecol 68: 1179-1192

Barrett RDH (2010) Adaptive evolution of lateral plates in 3spined stickleback Gasterosteus aculeatus: a case study in functional analysis of natural variation. J Fish Biol 77: 311-328

Beaumont MA (1999) Detecting population expansion and decline using microsatellites. Genetics 153:2013-2029

Beerli P, Felsenstein J (1999) Maximum-likelihood estimation of migration rates and effective population numbers in 2 populations using a coalescent approach. Genetics 152:763-773

Beerli P, Palczewski M (2010) Unified framework to evaluate panmixia and migration among multiple sampling locations. Genetics 185:313-326

Belkhir K, Borsa P, Chikhi L, Raufaste N, Bonhomme F (1996-2004) GENETIX 4.05, logiciel sous Windows TM pour la génétique des populations. Laboratoire Génome, Populations, Interactions, CNRS UMR 5000, Université de Montpellier II, Montpellier

Bell DA (1996) Genetic differentiation, geographic variation and hybridization in gulls of the Larus glaucescensoccidentalis complex. Condor 98:527-546

Birt TP, Carter HG, Whitworth DL, McDonald A and others (2012) Rangewide population genetic structure of Xantus's murrelet. Auk 129:44-55

Boessenkool S, Star B, Waters JM, Seddon PJ (2009) Multilocus assignment analyses reveal multiple units and rare migration events in the recently expanded yellow-eyed penguin (Megadyptes antipodes). Mol Ecol 18:2390-2400
Boessenkool S, Star B, Seddon PJ, Waters JM (2010) Temporal genetic samples indicate small effective population size of the endangered yellow-eyed penguin. Conserv Genet 11:539-546

Bollmer JL, Vargas F, Parker P (2007) Low MHC variation in the endangered Galapagos penguin (Spheniscus mendiculus). Immunogenetics 59:593-602

Bolton M, Smith AL, Gómez-Díaz E, Friesen VL and others (2008) Monteiro's storm-petrel Oceanodroma monteiroi: a new species from the Azores. Ibis 150:717-727

> Brown RM, Nichols RA, Faulkes CG, Jones CG and others (2010) Range expansion and hybridization in Round Island petrels (Pterodroma spp.): evidence from microsatellite genotypes. Mol Ecol 19:3157-3170

> Brumfield RT (2010) Speciation genetics of biological invasions with hybridization. Mol Ecol 19:5079-5083

Cairns DK, DeYoung B (1981) Back-crossing of a common murre (Uria aalge) and a common murre-thick-billed murre hybrid ( $U$. aalge x $U$. lomvia). Auk 98:847

Carneiro APB, Polito MJ, Sander M, Trivelpiece WZ (2010) Abundamce and spatial distribution of sympatrically breeding Catharacta spp. (skuas) in Admiralty Bay. Polar Biol 33:673-682

Cercueil A, Bellemain E, Manel S (2002) PARENTE: Computer Program for Parentage Analysis. J Hered 93:458-459

> Chu PC, Eisenschenk SK, Zhu ST (2009) Skeletal morphology and the phylogeny of skuas (Aves: Charadriiformes, Stercorariidae). Zool J Linn Soc 157:612-621

Coates BS, Sumerford DV, Miller NJ, Kim KS, Sappington TW, Siegfried BD, Lewis LC (2009) Comparative performance of single nucleotide polymorphism and microsatellite markers for population genetic analysis. J Hered 100:556-564

> Cohen BL, Baker AJ, Blechschmidt K, Dittmann DL and others (1997) Enigmatic phylogeny of the skuas (Aves: Stercorariidae). Proc Biol Sci 264:181-190

Corander J, Waldmann P, Sillanpää MJ (2003) Bayesian analysis of genetic differentiation between populations. Genetics 163:367-374

> Corander J, Waldmann P, Marttinen P, Sillanpää MJ (2004) BAPS 2: enhanced possibilities for the analysis of genetic population structure. Bioinformatics 20:2363-2369

> Cornuet JM, Luikart G (1996) Description and power analysis of 2 tests for detecting recent population bottlenecks from allele frequency data. Genetics 144:2001-2014

Cornuet JM, Santos F, Beaumont MA, Robert CP and others (2008) Inferring population history with DIY ABC: a userfriendly approach to approximate Bayesian computation. Bioinformatics 24:2713-2719

Coyne JA, Orr HA (2004) Speciation. Sinauer, Sunderland, MA

Csilléry K, Blum MGB, Gaggiotti OE, François O (2010) Approximate Bayesian Computation $(\mathrm{ABC})$ in practice. Trends Ecol Evol 25:410-418

Danzmann RG (1997) PROBMAX: A computer program for assigning unknown parentage in pedigree analysis from known genotypic pools of parents and progeny. J Hered $88: 333$

Deane P (2011) What traits predispose the band-rumped storm-petrel, Oceanodroma castro, to ecological speciation in the absence of physical barriers to gene flow? MSc Thesis, Queen's University, Kingston, ON

- Degnan JH, Rosenberg NA (2006) Discordance of species trees with this most likely gene trees. PLoS Genet 2:e68

> Degnan JH, Rosenberg NA (2009) Gene tree discordance, phylogenetic inference and the multispecies coalescent. Trends Ecol Evol 24:332-340

del Hoyo J, Elliott A, Sargatal J (1992) Handbook of the birds of the world, Vol 1. Lynx Edicions, Barcelona 
del Hoyo J, Elliott A, Sargatal J (1996) Handbook of the Birds of the World, Vol 3. Lynx Edicions, Barcelona

Drummond AJ, Rambaut A (2007) BEAST: Bayesian evolutionary analysis by sampling trees. BMC Evol Biol 7:214, doi:10.1186/1471-2148-7-214

Dupont S, Wilson K, Obst M, Sköld H, Nakano H, Thorndyke M (2007) Marine ecological genomics: when genomics meets marine ecology. Mar Ecol Prog Ser 332:257-273

Eda M, Kawakami K, Chiba H, Suzuki H, Horikoshi K, Koike $\mathrm{H}$ (2008) Genetic characteristics of the black-footed albatross (Diomedea nigripes) on the Bonin Islands and their implication for the species' demographic history and population structure. Ornitholog Sci 7:109-116

Ekblom R, Galindo J (2011) Applications of next generation sequencing in molecular ecology of non-model organisms. Heredity 107:1-15

Excoffier L, Heckel G (2006) Computer programs for population genetic analysis: a survival guide. Nat Rev Genet 7:745-758

Excoffier L, Laval G, Schneider S (2005) Arlequin ver. 3.0: An integrated software package for population genetics data analysis. Evol Bioinform Online 1:47-50

Faria PJ, Campos FP, Branco JO, Musso CM, Morgante JS, Bruford MW (2010) Population structure in the South American tern (Sterna hirundinacea) in the South Atlantic: two populations with distinct breeding phylogenies. J Avian Biol 41:378-387

Fay JJ, Nammack M (1996) Policy regarding the recognition of distinct vertebrate population segments under the Endangered Species Act. Fed Regist 61:4722-4725

Felsenstein J (1989) PHYLIP — Phylogeny Inference Package (Version 3.2). Cladistics 5:164-166

Foll M, Gaggiotti OE (2005) COLONISE: a computer program to study colonization processes in metapopulations. Mol Ecol Notes 5:705-707

Frankham R (2010) Challenges and opportunities of genetic approaches to biological conservation. Biol Conserv 143: 1919-1927

> Friesen VL, Anderson DJ (1997) Phylogeny and evolution of the Sulidae: a test of alternative modes of speciation. Mol Phylogenet Evol 7:252-260

Friesen VL, Barrett RT, Montevecchi WA, Davidson WS (1993) Molecular identification of a backcross between a female common murre/thick-billed murre hybrid and a male common murre. Can J Zool 71:1474-1477

Friesen VL, Piatt JF, Baker AJ (1996a) Evidence from cytochrome $b$ sequences and allozymes for a 'new' species of alcid: the long-billed murrelet (Brachyramphus perdix). Condor 98:681-690

Friesen VL, Montevecchi WA, Barrett RT, Davidson WS (1996b) Molecular evidence for kin groups in the absence of large-scale genetic differentiation in a migratory bird. Evolution 50:924-930

> Friesen VL, Birt TP, Piatt JF, Golightly RT, Newman SH, Hébert PN, Gissing G (2005) Population genetic structure in marbled murrelets (Brachyramphus marmoratus), and the delineation of 'distinct population segments' for conservation. Conserv Genet 6:607-613

Friesen VL, Smith AL, Gómez-Díaz EE, Bolton M, Furness RW, González-Solís J, Monteiro LR (2007a) Sympatric speciation by allochrony in a seabird. Proc Natl Acad Sci USA 104:18589-18594

Friesen VL, Burg TM, McCoy K (2007b) Mechanisms of population differentiation in seabirds. Mol Ecol 16:1765-1785

Gardner MG, Fitch AJ, Bertozzi T, Lowe AJ (2011) Rise of the machines-recommendations for ecologists when using next generation sequencing for microsatellite development. Mol Ecol Resour 11:1093-1101
Gay L, Neubauer G, Zagalska-Neubauer M, Debain C, Pons JM, David P, Crochet PA (2007) Molecular and morphological patterns of introgression between two large white-headed gull species in a zone of recent secondary contact. Mol Ecol 16:3215-3227

Gay L, Crochet PA, Bell DA, Lenormand T (2008) Comparing clines on molecular and phenotypic traits in hybrid zones: a window on tension zone models. Evolution 62: 2789-2806

Gay L, Neubauer G, Zagalska-Neubauer M, Pons JM, Bell DA, Crochet PA (2009) Speciation with gene flow in the large white-headed gulls: does selection counterbalance introgression? Heredity 102:133-146

Giudici A, Navarro J, Candelaria J, González-Solís J (2010) Physiological ecology of breeders and sabbaticals in a pelagic seabird. J Exp Mar Biol Ecol 389:13-17

Gómez-Díaz E, González-Solís J (2007) Geographic assignment of seabirds to their origin: combining morphologic, genetic, and biogeochemical analyses. Ecol Appl 17: 1484-1498

Gómez-Díaz E, González-Solís J, Peinado MA, Page RDM (2007) Lack of host-dependent genetic structure in ectoparasites of the Calonectris shearwaters. Mol Ecol 16:5204-5215

Gómez-Díaz E, González-Solís J, Peinado MA (2009) Population structure in a highly pelagic seabird, the Cory's shearwater Calonectris diomedea: an examination of genetics, morphology and ecology. Mar Ecol Prog Ser 382:197-209

Goudet J (1995) FSTAT (version 1.2): a computer program to calculate F-statistics. J Hered 86:485-486

Grémillet D, Boulinier T (2009) Spatial ecology and conservation of seabirds facing global climate change: a review. Mar Ecol Prog Ser 391:121-137

Griffiths RC, Tavaré S (1994) Simulating probability distributions in the coalescent. Theor Popul Biol 46:131-159

Guillot G, Estoup A, Mortier F, Cosson JF (2005) A spatial statistical model for landscape genetics. Genetics 170: 1261-1280

Haig SM, Mullins TD, Forsman ED, Trail PW, Wennerberg L (2004) Genetic identification of spotted owls, barred owls, and their hybrids: legal implications of hybrid identity. Conserv Biol 18:1347-1357

Haig SM, Bronaugh WM, Crowhurst RS, D'Elia J and others (2011) Genetic applications in avian conservation. Auk 128:205-229

Hailer F, Schreiber EA, Miller JM, Levin II, Parker PG, Chesser RT, Fleischer RC (2011) Long-term isolation of a highly mobile seabird on the Galapagos. Proc Biol Sci 278:817-825

Hall LA, Palsbøll PJ, Beissinger SR, Harvey JT and others (2009) Characterizing dispersal patterns in a threatened seabird with limited genetic structure. Mol Ecol 18: 5074-5085

> Hardy OJ, Vekemans X (2002) SPAGeDi: a versatile computer program to analyse spatial genetic structure at the individual or population levels. Mol Ecol Notes 2:618-620

Harrison RG (1993) Hybrid zones and the evolutionary process. Oxford University Press, New York, NY

> Hedgecock D, Lin JZ, DeCola S, Haudenschild CD, Meyer E, Manahan DT, Bowen B (2007) Transcriptomic analysis of growth heterosis in larval Pacific oysters. Proc Natl Acad Sci USA 104:2313-2318

- Helyar SJ, Hemmer-Hanser J, Bekkevold D, Taylor MI and others (2011) Application of SNPs for population genetics of nonmodel organisms: new opportunities and challenges. Mol Ecol Resour 11:123-136

$>$ Hey J (2006) Recent advances in assessing gene flow 
between diverging populations and species. Curr Opin Genet Dev 16:592-596

Hey J, Nielsen R (2004) Multilocus methods for estimating population sizes, migration rates and divergence time, with applications to the divergence of Drosophila pseudoobscura and D. persimilis. Genetics 167:747-760

- Hey J, Nielsen R (2007) Integration within the Felsenstein equation for improved Markov chain Monte Carlo methods in population genetics. Proc Natl Acad Sci USA 104: 2785-2790

- Holland BR, Spencer HG, Worthy TH, Kennedy M (2010) Identifying cliques of convergent characters: concerted evolution in the cormorants and shags. Syst Biol 59: $433-445$

Holsinger KE (1999) Analysis of genetic diversity in geographically structured populations: a Bayesian perspective. Hereditas 130:245-255

Hubbard JK, Uy JAC, Hauber ME, Hoekstra ME, Safram RJ (2010) Vertebrate pigmentation: from underlying genes to adaptive function. Trends Genet 26:231-239

Hudson ME (2008) Sequencing breakthroughs for genomic ecology and evolutionary biology. Mol Ecol Resour 8: $3-17$

- Huelsenbeck JP, Ronquist F (2001) MRBAYES: Bayesian inference of phylogeny. Bioinformatics 17:754-755

- Huyvaert KP, Anderson DJ (2004) Limited dispersal by Nazca boobies (Sula granti). J Avian Biol 35:46-53

> Huyvaert KL, Parker P (2010) Extra-pair paternity in waved albatrosses: genetic relationships among females, social mates and genetic sires. Behaviour 147:1591-1613

Ishak HD, Dumbacher JP, Anderson NL, Keane JJ and others (2008) Blood parasites in owls with conservation implications for the spotted owl (Strix occidentalis). PLoS ONE 3:e2304

Jesus J, Menezes D, Gomes S, Oliveira P, Nogales M, Brehm A (2009) Phylogenetic relationships of gadfly petrels Pterodroma spp. from northeastern Atlantic Ocean: molecular evidence for specific status of Bugio and Cape Verde petrels and implications for conservation. Bird Conserv Int 19:199-214

Jobb G, von Haeseler A, Strimmer K (2004) TREEFINDER: a powerful graphical analysis environment for molecular phylogenetics. BMC Evol Biol 4:18, doi:10.1186/14712148-4-18

Kelly BP, Whitely A, Tallmon D (2010) The Arctic melting pot. Nature 468:891

- Kennedy M, Page RDM (2002) Seabird supertrees: combining partial estimates of procellariiform phylogeny. Auk 119:88-108

Kennedy M, Spencer HG, Gray RD (1996) Hop, step and gape: do the social displays of the Pelecaniformes reflect phylogeny? Anim Behav 51:273-291

Kennedy M, Holland BR, Gray RD, Spencer HG (2005) Untangling long branches: identifying conflicting phylogenetic signals using spectral analysis, neighbour-net, and consensus networks. Syst Biol 54:620-633

Kennedy M, Valle CA, Spencer HG (2009) The phylogenetic position of the Galapagos cormorant. Mol Phylogenet Evol 53:94-98

Kim SY, Torres R, Rodriguez C, Drummond H (2007) Effects of breeding success, mate fidelity and senescence on breeding dispersal of male and female blue-footed boobies. J Anim Ecol 76:471-479

Kuhner MK (2006) LAMARC 2.0: maximum likelihood and Bayesian estimation of population parameters. Bioinformatics 22:768-770

Kuhner MK, Yamato J, Felsenstein J (1998) Maximum likelihood estimation of population growth rates based on the coalescent. Genetics 149:429-434

$>$ Leclaire S, Merkling T, Raynaud C, Mulard H and others (2012) Semiochemical compounds of preen secretion reflect genetic make-up in a seabird species. Proc Biol Sci 279:1185-1193

Lewis PO, Zaykin D (2002) Genetic data analysis: computer program for the analysis of allelic data. Version 1.1., http: //hydrodictyon.eeb.uconn.edu/people/plewis/software. php (accessed XXDATEXX)

> Librado P, Rozas J (2009) DnaSP v5: a software for comprehensive analysis of DNA polymorphism data. Bioinformatics 25:1451-1452

> Lipman DJ, Altschul SF, Kececioglu JD (1989) A tool for multiple sequence alignment. Proc Natl Acad Sci USA 86:4412-4415

- Liu L (2008) BEST: Bayesian estimation of species trees under the coalescent model. Bioinformatics 24:2542-2543

Lopes JS, Beaumont MA (2010) ABC: a useful Bayesian tool for the analysis of population data. Infect Genet Evol 10: 825-833

> Lopes JS, Boessenkool S (2010) The use of approximate Bayesian computation in conservation genetics and its application in a case study on yellow-eyed penguins. Conserv Genet 11:421-433

$>$ Maddison WP (1997) Gene trees in species trees. Syst Biol 46:523-536

Maddison DR, Maddison WP (1996) The Tree of Life Project. http://tolweb.org/tree/ (accessed XXDATEXX)

Maddison WP, Maddison DR (2011) Mesquite: a modular system for evolutionary analysis. Version 2.75, http: //mesquiteproject.org (accessed XXDATEXX)

> Manel S, Gaggiotti OE, Waples RS (2005) Assignment methods: matching biological questions with appropriate techniques. Trends Ecol Evol 20:136-142

Marshall TC, Slate J, Kruuk LEB, Pemberton JM (1998) Statistical confidence for likelihood-based paternity inference in natural populations. Mol Ecol 7:639-655

$>$ McCoy KD, Chapuis E, Tirard C, Boulinier T and others (2005a) Recurrent evolution of host-specialized races in a globally distributed parasite. Proc Biol Sci 272:2389-2395

McCoy KD, Boulinies T, Tirard C (2005b) Comparative hostparasite population structures: disentangling prospecting and dispersal in the black-legged kittiwake Rissa tridactyla. Mol Ecol 14:2825-2838

McCracken KG, Barger CP, Bulgarella M, Johnson KP and others (2009) Signatures of high-altitude adaptation in the major hemoglobin of five species of Andean dabbling ducks. Am Nat 174:631-650

> Milne I, Wright F, Rowe G, Marshall DF, Husmeier D, McGuire G (2004) TOPALi: software for automatic identification of recombinant sequences within DNA multiple alignments. Bioinformatics 20:1806-1807

Milot E, Weimerskirch H, Bernatchez L (2008) The seabird paradox: dispersal, genetic structure and population dynamics in a highly mobile, but philopatric albatross species. Mol Ecol 17:1658-1673

Mitchell-Olds T, Feder M, Wray G (2008) Evolutionary and ecological functional genomics. Heredity 100:101-102

Moen SM (1991) Morphologic and genetic variation among breeding colonies of the Atlantic puffin (Fratercula arctica). Auk 108:755-763

> Moritz C (1994) Applications of mitochondrial-DNA analysis in conservation - a critical review. Mol Ecol 3:401-411

$>$ Morris-Pocock JA, Taylor SA, Birt TP, Damus M, Piatt JF, Warheit KI, Friesen VL (2008) Population genetic structure in Atlantic and Pacific Ocean common murres (Uria aalge): natural replicate tests of post-Pleistocene evolution. Mol Ecol 17:4859-4873 
Morris-Pocock JA, Steeves T, Estela F, Anderson D, Friesen V (2010) Comparative phylogeograpbhy of brown (Sula leucogaster) and red-footed (S. sula) boobies: the influence of physical barriers and habitat preference on gene flow in pelagic seabirds. Mol Phylogenet Evol 54:883-896

Morris-Pocock JA, Anderson DJ, Friesen VL (2011) Mechanisms of global diversification in the brown booby (Sula leucogaster) revealed by uniting statistical phylogeography and multilocus phylogenetic methods. Mol Ecol 20: 2835-2850

Nelson JB (1970) The relationship between behaviour and ecology in the Sulidae with reference to other seabirds. Oceanogr Mar Biol Annu Rev 8:501-574

Nelson BJ (1978) The Sulidae: gannets and boobies. Aberdeen University Series, Oxford University Press, Oxford

Nieberding CM, Olivieri I (2007) Parasites: proxies for host genealogy and ecology? Trends Ecol Evol 22:156-165

Nielsen R, Wakeley J (2001) Distinguishing migration from isolation: a Markov chain Monte Carlo approach. Genetics 158:885-896

Nielsen R, Mattila DK, Clapham PJ, Palsbøll PJ (2001) Statistical approaches to paternity analysis in natural populations and applications to the North Atlantic humpback whale. Genetics 157:1673-1682

Nisbet ICT (1989) Long-term ecological studies of seabirds. Colon Waterbirds 12:143-147

Nunn GB, Stanley SE (1998) Body size effects and rates of cytochrome $b$ evolution in tube-nosed seabirds. Mol Biol Evol 15:1360-1371

Nunn GB, Cooper J, Jouventin P, Robertson CJR, Robertson GG (1996) Evolutionary relationships among extant albatrosses (Procellariiformes: Diomedeidae) established from complete cytochrome $b$ gene sequences. Auk 113: 784-801

Pacheco NM, Congdon BC, Friesen VL (2002) The utility of nuclear introns for investigating hybridization and genetic introgression: a case study involving Brachyramphus murrelets. Conserv Genet 3:175-182

Pagel M, Meade A (2004) A phylogenetic mixture model for detecting pattern-heterogeneity in gene sequence or character-state data. Syst Biol 53:571-581

Patterson SA, Morris-Pocock JA, Friesen VL (2011) A multilocus phylogeny of the Sulidae (Aves: Pelecaniformes). Mol Phylogenet Evol 58:181-191

Peery MZ, Beissinger SR, House RF, Bérubé M, Hall LA, Sellas A, Palsbøll PJ (2008) Characterizing source-sink dynamics with genetic parentage assignments. Ecology 89:2746-2759

Peery MZ, Hall LA, Sellas A, Beissinger SR and others (2010) Genetic analysis of historical and modern marbled murrelets suggesting decoupling of gene flow and migration after habitat fragmentation. Proc Biol Sci 277:697-706

Pereira SL, Baker AJ (2008) DNA evidence for a Paleocene origin of the Alcidae (Aves: Charadriiformes) in the Pacific and multiple dispersals across northern oceans. Mol Phylogenet Evol 46:430-445

Peucker AJ, Dann P, Burridge CP (2009) Range-wide phylogeography of the little penguin (Eudyptula minor): evidence of long-distance dispersal. Auk 126:397-408

Pinho C, Hey J (2010) Divergence with gene flow: models and data. Annu Rev Ecol Evol Syst 41:215-230

> Piry S, Alapetite A, Cornuet JM, Paetkau D, Baudouin L, Estoup A (2004) GeneClass2: a software for genetic assignment and first-generation migrant detection. J Hered 95:536-539

Pitocchelli J, Piatt JF, Cronin M (1995) Morphological and genetic divergence among Alaskan populations of Brachyramphus murrelets. Wilson Bull 107:235-250
Porter AH, Wenger R, Geiger H, Scholl A, Shapiro AM (1997) The Pontia daplidice-edusa hybrid zone in northwestern Italy. Evolution 51:1561-1573

Power DM, Ainley DG (1986) Seabird geographic variation: similarity among populations of Leach's storm petrel. Auk 103:575-585

Pritchard JK, Stephens M, Donnelly P (2000) Inference of population structure using multilocus genotype data. Genetics 155:945-959

> Rains D, Weimerskirch H, Burg TM (2011) Piecing together the global population puzzle of wandering albatrosses: genetic analysis of the Amsterdam albatross (Diomedea amsterdamensis). J Avian Biol 42:69-79

Raymond M, Rousset F (1995) GENEPOP (version 1.2): population genetics software for exact tests and ecumenicism. J Hered 86:248-249

> Rayner MJ, Hauber ME, Steeves TE, Lawrence HA and others (2011) Contemporary and historical separation of transequatorial migration between genetically distinct seabird populations. Nat Commun 2:332, doi:10.1038/ ncomms1330

Redelings BD, Suchard MA (2005) Joint Bayesian estimation of alignment and phylogeny. Syst Biol 54:401-418

Reinhardt K, Blechschmidt K, Peter HU, Montalti D (1997) A hitherto unknown hybridization between Chilean and south polar suka. Polar Biol 17:114-118

Riffaut L, McCoy KD, Tirard C, Friesen VL, Boulinier T (2005) Population genetics of Uria aalge in the North Atlantic: geographic impact of oil spills. Mar Ecol Prog Ser 291:263-273

Robertson BC, Stephenson BM, Goldstien SJ (2011) When rediscovery is not enough: taxonomic uncertainty hinders conservation of a critically endangered bird. Mol Phylogenet Evol 61:949-952

Rudnick JA, Katzner TE, Bragin EA, DeWoody JA (2008) A non-invasive genetic evaluation of population size, natal philopatry, and roosting behaviour of non-breeding eastern imperial eagles (Aquila heliaca) in central Asia. Conserv Genet 9:667-676

Sætre GP, Sæther SA (2010) Ecology and genetics of speciation in Ficedula flycatchers. Mol Ecol 19:1091-1106

Schlosser JA, Dubach JM, Garner TWJ, Araya B and others (2009) Evidence for gene flow differs from observed dispersal patterns in the Humboldt penguin, Spheniscus humboldti. Conserv Genet 10:839-849

Schluter D, Marchinko KB, Barret RDH, Rogers SM (2010) Natural selection and the genetics of adaptation in threespine stickleback. Philos Trans R Soc Lond B Biol Sci 365: 2479-2486

Schreiber EA, Burger J (eds) (2002) Biology of marine birds. CRC Press, Washington, DC

Schuster SC (2008) Next-generation sequencing transforms today's biology. Nat Methods 5:16-18

Selkoe KA, Henzler CH, Gaines SD (2008) Seascape genetics and the spatial ecology of marine populations. Fish Fish 9:363-377

Shendure J, Ji H (2008) Next-generation DNA sequencing. Nat Biotechnol 26:1135-1145

Sibley CG (1970) A comprehensive study of the egg white proteins of passerine birds. Peabody Museum of Natural History (Yale University), New Haven, CT

Sibley CG, Ahlquist JE (1990) Phylogeny and classification of birds, a study in molecular evolution. Yale University Press, New Haven, CT

Skillings DJ, Bird CE, Toonen RJ (2011) Gateways to Hawaii: genetic population structure of the tropical sea cucumber Holothuria atra. J Mar Biol 2011:1-16

- Smith ND (2010) Phylogenetic analysis of Pelecaniformes 
(Aves) based on osteological data: implications for waterbird phylogeny and fossil calibration studies. PLoS ONE 5:e13354

Snell RR (1991) Interspecific allozyme differentiation among North Atlantic white-headed gulls. Auk 108:319-328

Sork VL, Waits L (2010) Contributions of landscape genetics - approaches, insights, and future potential. Mol Ecol 19:3489-3495

Stapley J, Reger J, Feulner PGD, Smadja C and others (2010) Adaptation genomics: the next generation. Trends Ecol Evol 25:705-712

Steeves TE, Anderson DJ, McNally H, Kim MH, Friesen VL (2003) Phylogeography of Sula: the role of physical barriers to gene flow in the diversification of tropical seabirds. J Avian Biol 34:217-223

Steeves TE, Anderson DJ, Friesen VL (2005a) The Isthmus of Panama: a major physical barrier to gene flow in a highly mobile pantropical seabird. J Evol Biol 18:1000-1008

Steeves TE, Anderson DJ, Friesen VL (2005b) A role for nonphysical barriers to gene flow in the diversification of a highly vagile seabird, the masked booby (Sula dactylatra). Mol Ecol 14:3877-3887

Steeves TE, Holdaway RN, Hale ML, McLay E and others (2010) Merging ancient and modern DNA: extinct seabird taxon rediscovered in the North Tasman Sea. Biol Lett 6:94-97

Storer RW (1952) A comparison of variation, behavior and evolution in the sea bird genera Uria and Cepphus. Univ Calif Publ Zool 52:121-222

Strauch JG Jr (1985) The phylogeny of the Alcidae. Auk 102: 520-539

Swofford DL (2002) PAUP*: phylogenetic analysis using parsimony ( ${ }^{*}$ and other methods). Version 4. Sinauer Associates, Sunderland, MA.

Tamura K, Peterson D, Peterson N, Stcher G, Nei M, Kumar S (2011) MEGA5: molecular evolutionary genetics analysis using maximum likelihood, evolutionary distance, and maximum parsimony methods. Mol Biol Evol 28:2731-2739

Tautz D, Ellegren H, Weigel D (2010) Next generation molecular ecology. Mol Ecol 19:1-3

Taylor SA (2011) Evidence for speciation with gene flow: an examination of the evolutionary genetics of blue-footed and Peruvian boobies. PhD Thesis, Queen's University, Kingston, ON

Taylor SA, Zavalaga CB, Luna-Jorquera G, Simeone A, Anderson DJ, Friesen VL (2010a) Panmixia and high genetic diversity in a Humboldt Current endemic, the Peruvian booby (Sula variegata). J Ornithol 152:623-630

Taylor SA, Zavalaga CB, Friesen VL (2010b) Hybridization between blue-footed (Sula nebouxii) and Peruvian ( $S$. variegata) boobies in northern Peru. Waterbirds 33: 251-257

Taylor SA, Maclagan L, Anderson DJ, Friesen VL (2011a) Could specialization to cold water upwelling systems influence genetic diversity and gene flow in marine organisms? A case study using the blue-footed booby, Sula nebouxii. J Biogeogr 38:883-893

Taylor SA, Patirana A, Birt T, Friesen V (2011b) Cryptic introgression between murre sister species (Uria spp.) in the Pacific low Arctic: frequency, cause, and implications. Polar Biol. doi:10.1007/s00300-011-1141-8

Techow NMSM, O'Ryan C, Phillips R, Gales RA and others (2010) Speciation and phylogeography of giant petrels Macronectes. Mol Phylogenet Evol 54:472-487

Thomson RC, Wang IJ, Johnson JAR (2010) Genomeenabled development of DNA markers for ecology, evolution and conservation. Mol Ecol 19:2184-2195

Torres LG, Thompson DR, Bearhop S, Votier S, Taylor GA,
Sagar PM, Roberston BC (2011) White-capped albatrosses alter fine-scale foraging behaviour patterns when associated with fishing vessels. Mar Ecol Prog Ser 428: 289-301

Toth AL, Varala K, Henshaw MT, Rodrigues-Zas SL, Hudson ME, Robinson GE (2010) Brain transcriptomic analysis in paper wasps identifies genes associated with behaviour across social insect lineages. Proc Biol Sci 277:2139-2148

USFWS (US Fish and Wildlife Service) (1992) Endangered and threatened wildlife and plants; determination of threatened status for the Washington, Oregon and California population of the marbled murrelet. Fed Regist 57: 45328-45337

van Tets GF (1965) A comparative study of some social communication patterns in the Pelecaniformes. Ornithol Monogr 2:1-88

Vignal A, Milan D, SanCristobal M, Eggen A (2002) A review on SNP and other types of molecular markers and their use in animal genetics. Genet Sel Evol 34:275-305

Vines T, Mitchell E (2010) Special issue on landscape genetics. Mol Ecol 19(17):3489-3835

Walsh HE, Edwards SV (2005) Conservation genetics and fisheries by-catch: mitochondrial differentiation and population assignment in black-footed albatrosses (Phoebastria nigripes). Conserv Genet 6:289-295

- Wanless S, Frederiksen M, Daunt F, Scott BE, Harris MP (2007) Black-legged kittiwakes as indicators of environmental change in the North Sea: evidence from long term studies. Prog Oceanogr 72:30-38

> Watada M, Kakizawa R, Kuroda N, Utida S (1987) Genetic differentiation and phylogenetic relationships of an avian family, Alcidae (auks). J Yamashina Inst Ornithol 19:79-88

Weimenskirch H, Le Corre M, Ropert-Coudert Y, Kato A, Marsac F (2006) Sex-specific foraging behavious in a seabird with reversed sexual dimorphism: the red-footed booby. Behav Evol 146:681-691

- Welch AJ, Yoshida AA, Fleischer RC (2011) Mitochondrial and nuclear DNA sequences reveal recent divergence in morphologically indistinguishable petrels. Mol Ecol 20: 1364-1377

Wilson AC, Cann RL, Carr SM, George M and others (1985) Mitochondrial DNA and two perspectives on evolutionary genetics. Biol J Linn Soc 26:375-400

Wilson GA, Rannala B (2003) Bayesian inference of recent migration rates using multilocus genotypes. Genetics 163:1177-1191

Wilson RP, Vandenabeele S (2012) Technological innovation in archival tags used in seabird research. Mar Ecol Prog Ser 451:245-262

> Wojczulanis-Jakubas K, Jakubas D, Øigarden T, Lifjeld JT (2009) Extrapair copulations are frequent but unsuccessful in a highly colonial seabird, the little auk, Alle alle. Anim Behav 77:433-438

- Wojczulanis-Jakubas K, Dynowska M, Jakubas D (2011) Fungi prevalence in breeding pairs of a monogamous seabird - little auk, Alle alle. Ethol Ecol Evol 23:240-247

- Wooller RD, Bradley JS, Croxall JP (1992) Long-term population studies of seabirds. Trends Ecol Evol 7:111-114

Yang Z (1997) PAML: a program package for phylogenetic analysis by maximum likelihood. Comput Appl Biosci 13: 555-556

Young LC (2010) Inferring colonization history and dispersal patterns of a long-lived seabird by combining genetic and empirical data. J Zool (Lond) 281:232-240

Zavalaga CBZ, Taylor SA, Dell'Omo G, Anderson DJ, Friesen VL (2009) Male/female classification of the Peruvian booby. Wilson J Ornithol 121:739-744 